\title{
Review \\ Targeting the Intrinsic Apoptosis Pathway: A Window of Opportunity for Prostate Cancer
}

\author{
Daniel Westaby ${ }^{1,2}$, Juan M. Jimenez-Vacas ${ }^{1}$, Ana Padilha ${ }^{1}$, Andreas Varkaris ${ }^{3}$, Steven P. Balk ${ }^{3}$, \\ Johann S. de Bono ${ }^{1,2}$ and Adam Sharp ${ }^{1,2, *}$ \\ 1 Division of Clinical Studies, The Institute of Cancer Research, London SM2 5NG, UK; \\ daniel.westaby@icr.ac.uk (D.W.); juan.jimenezvacas@icr.ac.uk (J.M.J.-V.); ana.primpadilha@icr.ac.uk (A.P.) \\ Johann.DeBono@icr.ac.uk (J.S.d.B.) \\ 2 Prostate Cancer Targeted Therapy Group, The Royal Marsden Hospital, London SM2 5PT, UK \\ 3 Hematology-Oncology Division, Beth Israel Deaconess Medical Center, Boston, MA 02215, USA; \\ avarkaris@mgh.harvard.edu (A.V.); sbalk@bidmc.harvard.edu (S.P.B.) \\ * Correspondence: adam.sharp@icr.ac.uk
}

Citation: Westaby, D.; Jimenez-Vacas, J.M.; Padilha, A.; Varkaris, A.; Balk, S.P.; de Bono, J.S.; Sharp, A. Targeting the Intrinsic Apoptosis Pathway: A Window of Opportunity for Prostate Cancer. Cancers 2022, 14, 51. https://doi.org/10.3390/ cancers14010051

Academic Editor: Fred Saad

Received: 23 November 2021 Accepted: 15 December 2021

Published: 23 December 2021

Publisher's Note: MDPI stays neutral with regard to jurisdictional claims in published maps and institutional affiliations.

Copyright: (C) 2021 by the authors. Licensee MDPI, Basel, Switzerland. This article is an open access article distributed under the terms and conditions of the Creative Commons Attribution (CC BY) license (https:/ / creativecommons.org/licenses/by/ $4.0 /)$.
Simple Summary: Prostate cancer treatment has improved over the last 20 years; despite this, approximately 33,000 men died from the disease in the United States in 2020. In view of this, new treatment options are urgently needed for advanced prostate cancer. Eradicating cancer cells by triggering apoptosis (a form of cell death) is an attractive strategy, and a novel class of drugs, called BH3 mimetics, have been designed to do this. They have been shown to work for blood cancers and may also have a role in solid cancers. Herein, we discuss cell death, focusing on the intrinsic apoptosis pathway, and consider how $\mathrm{BH} 3$ mimetics may be used to help treat prostate cancer.

\begin{abstract}
Despite major improvements in the management of advanced prostate cancer over the last 20 years, the disease remains invariably fatal, and new effective therapies are required. The development of novel hormonal agents and taxane chemotherapy has improved outcomes, although primary and acquired resistance remains problematic. Inducing cancer cell death via apoptosis has long been an attractive goal in the treatment of cancer. Apoptosis, a form of regulated cell death, is a highly controlled process, split into two main pathways (intrinsic and extrinsic), and is stimulated by a multitude of factors, including cellular and genotoxic stress. Numerous therapeutic strategies targeting the intrinsic apoptosis pathway are in clinical development, and BH3 mimetics have shown promising efficacy for hematological malignancies. Utilizing these agents for solid malignancies has proved more challenging, though efforts are ongoing. Molecular characterization and the development of predictive biomarkers is likely to be critical for patient selection, by identifying tumors with a vulnerability in the intrinsic apoptosis pathway. This review provides an up-to-date overview of cell death and apoptosis, specifically focusing on the intrinsic pathway. It summarizes the latest approaches for targeting the intrinsic apoptosis pathway with $\mathrm{BH} 3$ mimetics and discusses how these strategies may be leveraged to treat prostate cancer.
\end{abstract}

Keywords: prostate cancer; cell death; apoptosis; $\mathrm{BH} 3$ mimetics

\section{Introduction}

Prostate cancer is the most frequently occurring cancer in men in the Western world, and was responsible for approximately 330,000 deaths in the United States in 2020 [1,2]. Around three-quarters of men with prostate cancer are diagnosed with localized disease and can be treated with curative intent; most commonly using a radical prostatectomy or radiotherapy [3]. However, an increasing number, and percentage, of men are being diagnosed with de novo metastatic disease, and relapse occurs in 20 to $50 \%$ after radical treatment of early-stage disease [3-7]. Prostate cancer is predominantly an androgendependent disease, and androgen deprivation therapy (ADT; herein defined as medical 
or surgical castration) has remained the backbone of treatment for advanced disease since 1941, when Charles Huggins and Clarence Hodges discovered its beneficial effect for men with metastatic disease [8-11].

The majority of advanced prostate cancers respond to ADT, but they inevitably progress from castration-sensitive prostate cancer (CSPC) to castration-resistant prostate cancer (CRPC), which is driven by a range of androgen receptor (AR)-dependent and independent mechanisms (e.g., $A R$ amplification and neuroendocrine trans-differentiation, respectively) [12]. Despite significant progress in management over the last 20 years, advanced CRPC remains lethal, with a poor prognosis and an estimated median survival of between 2 and 3 years $[13,14]$. Life-prolonging treatments for advanced CRPC include taxane-based chemotherapy (docetaxel and cabazitaxel), novel hormonal agents (abiraterone and enzalutamide), a bone specific alpha-emitting radionuclide (radium-223), and an autologous cellular immunotherapy (sipuleucel-T) [15-23]. These agents were initially approved for advanced CRPC, though subsequent clinical trials have shown that docetaxel and novel hormonal agents (abiraterone, enzalutamide, and apalutamide) are also effective when utilized earlier in the disease course for advanced CSPC [24-29].

Advanced prostate cancer is a heterogenous disease with a multitude of primary and acquired treatment resistance mechanisms [30,31]. Molecular characterization and the identification of clinically useful predictive biomarkers is of high importance for patient selection. In this space, in recent years, aberrations in homologous recombination repair (HRR) and DNA damage response (DDR) genes have been shown to sensitize tumors to poly(ADP-ribose) polymerase (PARP) inhibitors via synthetic lethality, and have subsequently been approved by the FDA for this subset of metastatic CRPC [32,33]. PTEN loss is emerging as a predictive biomarker for response to AKT inhibition, and the anti-PD-1 agent pembrolizumab has been approved for all advanced solid tumors with defective mismatch repair or microsatellite instability-high, including advanced prostate cancer [34-36]. PSMA (prostate-specific membrane-antigen) is highly expressed in most prostate cancers, especially in CRPC $[37,38] .{ }^{177}$ Lutetium-PSMA-617, a PSMA ligand labelled with a betaemitting radionuclide lutetium-177, accumulates at PSMA expressing tumor sites, inducing cancer cell death, and has recently been shown to be effective for men with advanced PSMA-positive CRPC [39]. Although these therapies have improved outcomes for men with advanced prostate cancer, none of them are curative, and new effective treatment strategies are urgently required.

Apoptosis, a form of regulated cell death, can be divided into the intrinsic and extrinsic pathways. Established therapies for advanced prostate cancer, including ADT and chemotherapy, induce cellular stress and can subsequently activate the intrinsic apoptosis pathway, but have limited success in doing this [40-42]. Although ADT does induce apoptosis in a minority of prostate cancers, the predominant mechanisms of tumor regression are reduced proliferation, cell cycle arrest, and senescence, allowing cancer cells to adapt under therapeutic pressure [42-45]. In contrast, eliminating cancer cells by triggering apoptosis will, in theory, reduce the chances of therapeutic resistance. The intrinsic apoptosis pathway is tightly regulated by a range of pro- and anti-apoptotic B-cell lymphoma 2 (BCL-2) family proteins [46]. Achieving apoptotic cancer cell death is reliant on breaching the apoptotic threshold, and upregulation of anti-apoptotic BCL-2 family proteins has been shown to promote tumor progression, androgen independence, and treatment resistance [47-55]. As such, targeting the intrinsic apoptosis pathway is an attractive therapeutic strategy for advanced prostate cancer, though molecular characterization and the identification of tumors with a dependency and/or vulnerability will be critical to best utilize this approach.

This review provides an up-to-date overview of cell death and apoptosis, specifically focusing on the intrinsic pathway. It summarizes the latest approaches for targeting the intrinsic apoptosis pathway with BCL-2 homology domain 3 (BH3) mimetics, and discusses how these strategies may be leveraged to treat prostate cancer. 


\section{Cell Death: Multiple Ways to Die}

Cell death is a critical part of organismal homeostasis, maintaining balance between new cell generation by mitosis and the removal of damaged or unwanted cells. Historically, morphological classification has been used to characterize cell death into three main processes: apoptosis, necrosis, and autophagy (Table 1) [56]. However, in recent years, as understanding has developed, there has been a push to move away from morphological classification, and, since 2005, the Nomenclature Committee on Cell Death (NCCD) has proposed an updated classification of cell death modalities based on the mechanistic and requisite aspects of the process [57].

Table 1. Historical classification of cell death based on stereotypical morphology.

\begin{tabular}{|c|c|c|}
\hline Morphotype & Stereotypical Morphological Changes & Diagram \\
\hline Apoptosis (Type 1 cell death) & $\begin{array}{l}\text { - } \quad \text { Cytoplasmic shrinkage. } \\
\text { - } \quad \text { Chromatin condensation. } \\
\text { - } \quad \text { Plasma membrane blebbing. } \\
\text { - } \quad \text { Pormation of apoptotic bodies. } \\
\text { bodies. } \\
\text { - Degradation of apoptotic bodies in } \\
\text { lysosomes. }\end{array}$ & \\
\hline Autophagy (Type 2 cell death) & $\begin{array}{l}\text { - Extensive cytoplasmic } \\
\text { vacuolization. } \\
\text { - Formation of autophagosomes. } \\
\text { Fusion of autophagosomes with } \\
\text { lysosomes. }\end{array}$ & \\
\hline
\end{tabular}

Necrosis (Type 3 cell death)

- Cytoplasmic and organelle swelling.

- Rupture of plasma membrane.

- Release of cellular contents.

Historically defined as cell death in the absence of apoptotic or autophagic morphological features.

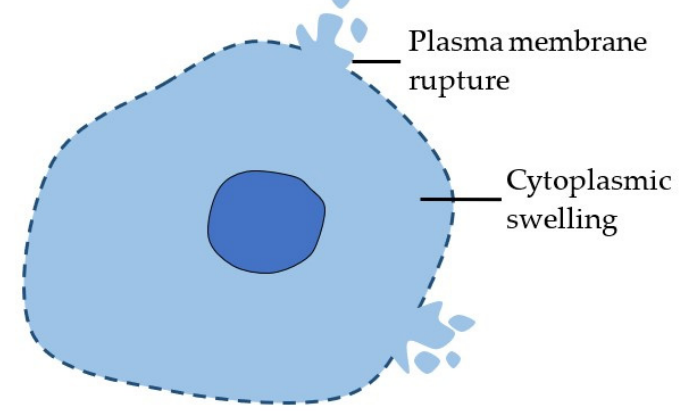

Cells can either die from accidental cell death (ACD) or regulated cell death (RCD) (Table 2). ACD is an uncontrolled process characterized by the sudden catastrophic demise of cells after exposure to a range of physical (e.g., extreme temperature), chemical (e.g., $\mathrm{pH}$ variation), or mechanical insults. In contrast, RCD is a highly coordinated process dependent on the activation of one or more genetically encoded signal transduction pathways. RCD can occur in two contrasting situations: (1) in response to intra- or extracellular perturbations when adaptive responses fail to restore cellular homeostasis, or (2) as part of routine physiological processes such as tissue development, turnover, and remodeling (often referred to as programmed cell death) [57,58]. There are a multitude of RCD mechanisms, with significant interconnectivity, all of which can exhibit a range of morphological features (from apoptotic to necrotic) (Table 2) [57]. 
Table 2. Mechanistic classification of cell death (adapted from Galluzzi et al.; 2018) [57].

\begin{tabular}{|c|c|}
\hline Cell Death Type & Definition \\
\hline Accidental cell death (ACD) & $\begin{array}{l}\text { Rapid and uncontrolled cell death triggered by extreme } \\
\text { physical, chemical, or mechanical insults and } \\
\text { characterized by plasma membrane rupture. }\end{array}$ \\
\hline Regulated cell death (RCD) & $\begin{array}{l}\text { Highly coordinated cell death, dependent on the } \\
\text { activation of one or more signal transduction pathways. } \\
\text { RCD can be subdivided into numerous subroutines with } \\
\text { significant interconnectivity, all of which can present } \\
\text { with a range of morphological features (apoptotic to } \\
\text { necrotic) and immunomodulatory effects. } \\
\text { Subroutines include intrinsic apoptosis, extrinsic } \\
\text { apoptosis, mitochondrial permeability transition } \\
\text { (MPT)-driven necrosis, necroptosis, ferroptosis, } \\
\text { pyroptosis, parthanatos, entotic cell death, NETotic cell } \\
\text { death, lysosome-dependent cell death, } \\
\text { autophagy-dependent cell death, and immunogenic cell } \\
\text { death (see NCCD classification, Galluzzi et al.; 2018). }\end{array}$ \\
\hline Programmed Cell Death (PCD) & $\begin{array}{l}\text { Regulated cell death that occurs as part of normal } \\
\text { physiological processes. }\end{array}$ \\
\hline
\end{tabular}

Apoptosis, a form of RCD, is characterized by caspase-dependent proteolysis, endonucleolytic DNA fragmentation, membrane blebbing, and the formation of apoptotic bodies which are subsequently engulfed by resident phagocytes [59]. Apoptosis was historically thought to be an immunologically silent process, but it has become evident that this is not always the case [60]. Apoptosis can be triggered by two core pathways: extrinsic and intrinsic. The extrinsic pathway is stimulated by perturbations in the extracellular microenvironment, which trigger death receptors on the cell membrane (including Fas, TNF, and TRAIL), leading to activation of caspase 8 and subsequent activation of effector caspases, such as caspase 3 . In 'type I cells', there is sufficient stimulation of the effector caspases to drive cell death, independent of the intrinsic pathway [61,62]. However, in 'type II cells', which includes most cancer cells, the extrinsic pathway relies on cleavage of BID by caspase 8 to form truncated BID (tBID). tBID subsequently translocates to the mitochondria and stimulates the intrinsic pathway by inducing BAX/BAK-dependent mitochondrial outer membrane permeabilization (MOMP), release of cytochrome $\mathrm{c}$, and caspase 9-driven cell death [63-65].

Whilst deregulation of apoptosis is widely recognized to be a crucial part of tumorigenesis and treatment resistance, other forms of cell death may also play a role, and could be leveraged for therapeutic benefit. For example, necroptosis is a caspase-independent form of RCD, presenting with a necrotic morphotype, and may trigger anti-tumor immunity. Mechanistically, necroptosis critically depends on the activation of RIPK3 and MLKL [57]. Interestingly, RIPK3 has been shown to be downregulated in prostate cancer, and its overexpression suppressed prostate cancer cell migration and invasion [66]. Ferroptosis, another form of RCD, is characterized by iron-dependent lipid peroxidation, and a recent study demonstrated anti-tumor activity in prostate cancer cell line mouse xenograft models with ferroptosis inducing agents [67].

\section{The Intrinsic Apoptosis Pathway}

The intrinsic apoptosis pathway, also known as the 'stress' or 'mitochondrial' apoptosis pathway, is tightly regulated by BCL-2 proteins; a family of pro- and anti-apoptotic proteins which share between one and four BCL-2 homology (BH) domains (BH1, BH2, BH3, BH4) and interact on the mitochondrial outer membrane [68]. The pro-apoptotic BCL-2 proteins can be subcategorized as BH3-only 'activators' (BIM, BID, PUMA), BH3-only 'sensitizers' (BAD, NOXA, HRK, BIK, BMF), and pore-forming 'effectors' (BAX, BAK). Counteracting these are the anti-apoptotic/pro-survival BCL-2 proteins, including MCL-1, BCL-2, BCL-XL, 
BCL-W, and BFL-1 (Figure 1) [69]. The balance between pro- and anti-apoptotic BCL-2 family proteins is critical in determining cell fate decisions, and manipulating this balance to breach the apoptotic threshold is an attractive strategy in cancer therapeutics [70].

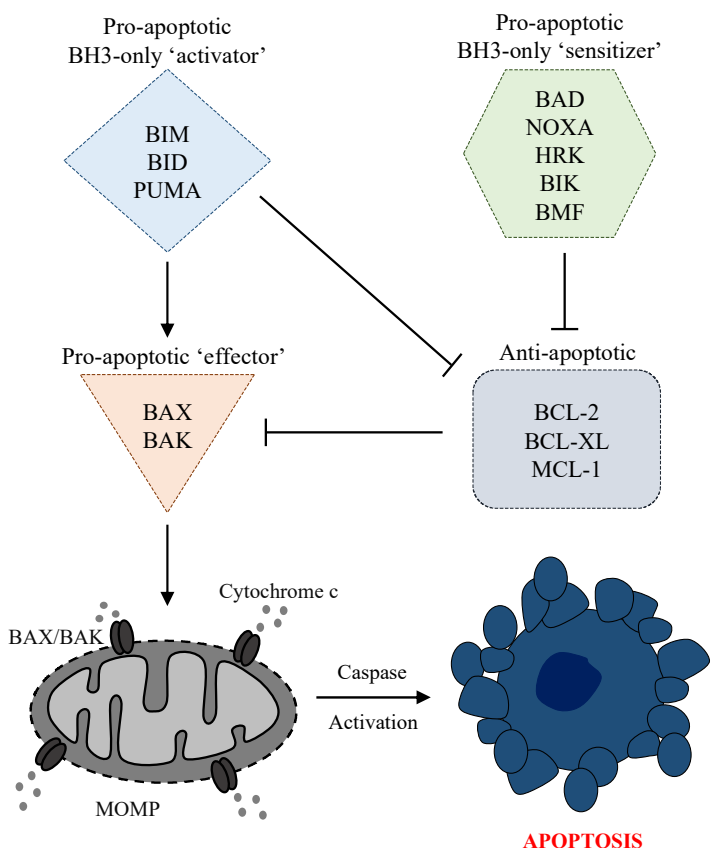

Figure 1. The intrinsic apoptosis pathway is tightly regulated by pro- and anti-apoptotic BCL2 proteins which interact on the mitochondrial outer membrane. Pro-apoptotic BCL-2 proteins can be subcategorized as BH3-only 'activators' (BIM, BID, PUMA), BH3-only 'sensitizers' (BAD, NOXA, HRK, BIK, BMF) and pore-forming 'effectors' (BAK, BAX). Counteracting these are antiapoptotic/pro-survival BCL-2 proteins including MCL-1, BCL-2, BCL-XL which sequester proapoptotic BCL-2 family members. BH3-only 'activators' promote apoptosis by directly engaging and activating BAX/BAK, as well as sequestering anti-apoptotic BCL-2 proteins. BH3-only 'sensitizers' are unable to directly engage BAX/BAX and primarily function by sequestering anti-apoptotic members. The induction of BH3-only proteins in response to cell death stimuli can trigger BAX/BAK homooligomerization, the formation of macropores, mitochondrial outer membrane permeabilization (MOMP), the release of cytochrome $\mathrm{c}$ and caspase driven apoptotic cell death.

A range of cellular stress and cell death stimuli, such as DNA damage (including that from DNA-targeting anti-cancer agents and radiation), replication stress, growth factor deprivation, and endoplasmic reticulum stress can initiate intrinsic apoptosis by inducing BH3-only 'activator' and/or 'sensitizer' proteins via transcriptional upregulation or posttranslational modification $[57,69]$. For example, p53 induces PUMA and NOXA mRNA transcription in response to DNA damage, thereby priming the cell for apoptosis [71,72]. In response to these cell death stimuli, BH3-only 'activator' proteins (BIM, BID, PUMA) can bind directly to, and activate, the 'effector' proteins (BAX and/or BAK). In addition to direct stimulation of BAX and BAK, the BH3-only 'activator' proteins also bind to and sequester anti-apoptotic/pro-survival BCL-2 family proteins.

$\mathrm{BH} 3$-only proteins that lack the capability to directly engage BAX and BAK are termed 'sensitizer' proteins (BAD, NOXA, HRK, BIK, BMF), and predominantly act by inhibiting anti-apoptotic proteins [73]. Anti-apoptotic members of the BCL-2 family (MCL-1, BCL-2, BCL-XL, BCL-W, BFL-1) contain all four BH domains and enact their pro-survival function by directly binding to, and sequestering, pro-apoptotic BCL-2 proteins (Figure 1). These pro-survival proteins contain a hydrophobic groove, formed by the first three $\mathrm{BH}$ domains (BH1-3), which is able to bind to the hydrophobic face of pro-apoptotic proteins in a highly selective manner. Of note, $\mathrm{BH} 3$-only proteins have varying binding affinities for different anti-apoptotic proteins, as they also do with pro-apoptotic 'effector' proteins [74]. 
Mounting evidence suggests that BH3-only proteins can also induce apoptosis by sequestering anti-apoptotic proteins away from BAK and BAX, allowing them to autoactivate, without the need for direct activation [75-78]. Once activated, BAX/BAK undergo homo-oligomerization and form macropores, leading to MOMP and subsequent release of cytochrome $\mathrm{c}$ from the mitochondrial intermembrane space. Cytochrome $\mathrm{c}$ binds to APAF-1 to form the apoptosome, which activates caspase 9 . Caspase 9 subsequently activates the effector caspases, including caspase 3 and 7, which disassemble the cell in preparation for phagocytosis. Counteracting the apoptosome and caspase activation are a family of inhibitor of apoptosis (IAP) proteins, which can in turn be inhibited by Smac and Omi proteins [79].

Although effector caspases are widely acknowledged to precipitate apoptosis, their stimulation is not essential for the process, and inhibiting caspase activation does not prevent cell death $[59,80]$. Preventing post-mitochondrial caspase activation, either with genetic manipulation or pharmacological inhibitors, does, however, delay intrinsic apoptosis and promote conversion to other forms of RCD [59]. MOMP has historically been seen as the point of no return, but if permeabilization only occurs in a limited number of mitochondria, the activation of caspases is not sufficient to drive cell death; however, it has been shown to induce DNA damage and genomic instability [81].

The susceptibility of healthy cells to apoptosis varies greatly in normal tissues, depending on organ type and stage of development, and primarily relies on the balance between pro- and anti-apoptotic BCL-2 family proteins. In early life, during tissue development, MYC-driven transcription of pro-apoptotic genes primes cells for apoptosis, allowing the removal of unwanted or damaged cells generated by high proliferation [82]. This renders developing organs highly susceptible to various insults, and accounts for the high levels of neuro- and cardiotoxicity observed when young children are treated with DNA-damaging agents, including chemotherapy and radiation. Over time, during post-natal tissue development, post-mitotic tissues, including the heart and brain, become refractory to apoptosis, primarily due to downregulation of BAX and BAK [82,83]. At the other end of the spectrum, cells of hematopoietic lineage, including peripheral mononuclear, thymus, spleen, and bone marrow remain highly primed for apoptosis throughout life, which explains the high incidence of myelosuppression during cytotoxic chemotherapy [82]. The susceptibility of normal tissues to apoptosis must be considered when developing strategies to trigger this pathway in cancer therapy.

\section{Evasion of Apoptosis in Cancer}

Owing to oncogenic DNA damage, aberrant growth signals, and increased cell cycling, the transformation of a cell to a malignant state is inherently stressful, and primes cells for apoptosis, serving as a natural barrier to oncogenesis [84]. Many of the genes responsible for cell growth and proliferation are controlled by MYC, explaining the deregulation of this oncogene in the majority of malignancies, including prostate cancer [85]. MYC is one of the most highly expressed genes in prostate cancer, and has been shown to positively regulate the $A R$ and its splice variants [86]. As previously discussed, MYC drives upregulation of pro-apoptotic proteins and contributes to apoptotic priming during neoplastic transformation. However, as tumorigenesis progresses, cancer cells acquire the means to circumvent apoptosis; evasion of apoptosis is an established 'hallmark of cancer' [87]. Cancer cells encounter cumulative stresses during tumor progression, including genomic instability, nutrient deficiency, and hypoxia, and to metastasize they must be refractory to detachment-induced apoptosis (anoikis) [88,89]. Cancer cells can adapt to escape these cell death stimuli by modifying their intrinsic apoptosis machinery, either by upregulation of anti-apoptotic, or downregulation of pro-apoptotic, BCL-2 proteins. A growing body of evidence suggests this is the case in prostate cancer, an aspect of which is discussed in detail later in this review. This can occur via a multitude of mechanisms, including gene amplification, chromosomal translocation, transcriptional/translational regulation, or post-translational modifications [90,91]. Post-translational modifications include phospho- 
rylation and regulation of protein stability via the ubiquitin proteasome system, especially of MCL-1 and BIM, which are both characterized by rapid turnover and short half-life [91]. For example, phosphorylation of MCL-1 by GSK3 is known to promote its degradation by recruiting E3 ubiquitin ligases including beta-TRCP and FBW7 [92,93]. In contrast, a range of deubiquitinating enzymes, such as Usp9x, counteract this process and help stabilize MCL-1 [94].

\section{Interrogating BCL-2 Protein Dependency}

Given the abundance of BCL-2 proteins, along with their complex interactions and context-dependent activity, it is challenging to analyze mitochondrial apoptotic sensitivity with biochemical assays. Although the relative levels of BCL-2 proteins correlate with sensitivity to $\mathrm{BH} 3$ mimetics in some malignancies, this is not uniformly observed, and the measurement of RNA or protein levels does not account for protein activity or important interactions [95-99]. For example, in patients with chronic lymphocytic leukemia (CLL), low MCL1 expression and high BIM:MCL-1 or BIM:BCL-2 ratios correlate with increased response to navitoclax (BCL-2/BCL-XL/BCL-W inhibitor) [95]. On the other hand, in myeloma cells, the binding of BIM to BCL-XL and BCL-2, but not the expression pattern, is associated with sensitivity to ABT-737 (BCL-2/BCL-XL/BCL-W inhibitor) [97]. In view of this complexity, over the last 15 years, 'dynamic BH3 profiling' assays have been developed to functionally measure cellular response to defined pro-apoptotic signals, using a range of $\mathrm{BH} 3$ peptides, allowing investigators to: (1) assess cellular susceptibility to intrinsic apoptosis ('priming') and (2) evaluate dependencies on specific anti-apoptotic proteins [100,101]. As specific 'sensitizer' BH3-only proteins have different affinities for anti-apoptotic proteins, it is possible to use certain peptides, which mimic the activity of 'sensitizer' proteins, to elucidate the dependency of cells to specific anti-apoptotic proteins. For example, NOXA preferentially inhibits MCL-1, whereas HRK preferentially inhibits BCL-XL [100]. Other approaches to elucidate dependencies include utilizing CRISPR/cas9 genome-editing technology to silence specific anti-apoptotic BCL-2 proteins, or exposing tumor models to a range of BH3 mimetics (see below) [102,103]. Pre-treatment mitochondrial priming has been shown to correlate with response to cytotoxic chemotherapy in patients with ovarian cancer, multiple myeloma, and acute myelogenous and lymphoblastic leukemia [70]. Using these technologies to elucidate sensitivity to agents targeting the intrinsic apoptosis machinery may help identify predictive biomarkers for this strategy.

\section{Targeting the Intrinsic Apoptosis Pathway with BH3 Mimetics}

Recent advances in medicinal chemistry have enabled the development of agents targeting the intrinsic apoptosis pathway. IAP inhibitors and Smac mimetics are currently being evaluated in early phase trials, although the most clinically advanced agents are the $\mathrm{BH} 3$ mimetics, which this review will focus on. $\mathrm{BH} 3$ mimetics are a range of small molecules designed to mimic the binding of $\mathrm{BH} 3$-only proteins to the hydrophobic groove on anti-apoptotic BCL-2 proteins, thereby liberating BAX/BAK to spontaneously activate and/or release $\mathrm{BH} 3$-only proteins to exert their pro-apoptotic effect on BAX/BAK. Venetoclax, a BCL-2 inhibitor, is currently the only agent with FDA approval that directly targets the intrinsic apoptosis machinery. First generation 'pan-BH3 mimetics', such as AT-101 and obatoclax, inhibited all anti-apoptotic BCL-2 family proteins, though off-target doselimiting toxicities halted their clinical development [104,105]. In fact, subsequent studies showed that AT-101 and obatoclax were not authentic BH3 mimetics, as their pro-apoptotic activity resulted from off-target effects [106]. Next generation BH3 mimetics, mirroring endogenous $\mathrm{BH} 3$-only proteins, have been developed to have varying affinities for specific anti-apoptotic proteins. ABT-737, the first authentic BH3 mimetic, was developed to selectively inhibit BCL-2, BCL-XL and BCL-W, and showed promising activity against lymphoma and small-cell lung carcinoma mouse xenograft models, providing proof of principle for this therapeutic approach [107]. However, owing to its unfavorable pharmacokinetic properties, an orally bioavailable successor, navitoclax (ABT-263), was developed [108]. 
Navitoclax entered clinical trials in 2005, and although its clinical development has been hindered by dose-dependent thrombocytopenia, related to the inhibition of BCL-XL on platelets, it continues to be evaluated for myelofibrosis, as well as a range of advanced solid tumors, primarily in combination with tyrosine kinase inhibitors [109,110].

\subsection{Selective BCL-2 Targeting}

To mitigate the toxicity associated with BCL-XL inhibition, venetoclax (ABT-199), a highly selective BCL-2 inhibitor, was developed [111]. Venetoclax demonstrated strong anti-cancer activity in a variety of hematological malignancies with manageable toxicity, and has subsequently been approved by the FDA as a single agent, or in combination with rituximab or obinutuzumab, for the treatment of CLL and small lymphocytic lymphoma, as well as in combination with azacitidine, decitabine, or low-dose cytarabine for the treatment of acute myeloid leukemia (AML) [111-116]. In relapsed CLL, using pooled data from 4 early-phase trials, single agent venetoclax induced objective responses in $75 \%$ of patients, including $22 \%$ who achieved a complete response [117]. For patients with untreated AML who were not eligible for standard induction therapy (due to comorbidities or $>75$ years of age), the combination of venetoclax and azacitidine improved median overall survival from 9.6 to 14.7 months compared to azacitidine alone, with an improvement in complete response rate from $17.9 \%$ to $36.7 \%$ [113]. The success of BCL-2 inhibition in hematological cancers has been attributed to the upregulation of, and dependency on, BCL-2. Multiple studies have shown high BCL-2 tumor cell expression associated with venetoclax sensitivity; however, this is not uniformly observed, suggesting this is not the only factor determining response [111,118-122]. For example, there is high and uniform expression of BCL-2 in follicular lymphoma, though response to venetoclax is limited, demonstrating that its predictive use is context dependent [118].

Although venetoclax has proven efficacious for hematological malignancies, relapse is common and multiple resistance mechanisms have been described, including mutations in BCL-2, upregulation of MCL-1 and BCL-XL, TP53 dysfunction, and BAX loss [123-126]. Moreover, BCL-2 inhibition appears to have limited efficacy in solid tumors. A highthroughput venetoclax drug screen in cell lines from 26 different solid cancer types revealed limited activity, apart from in a subset of small-cell lung cancer (SCLC), bone and nervous system tumors [127]. In SCLC, high BCL-2 expression was found to correlate with sensitivity to venetoclax in cell lines and patient-derived xenograft models [127]. Although single agent activity appears to be limited in solid tumors, several pre-clinical studies have shown efficacy for venetoclax in combination with other agents, and multiple early phase clinical trials are ongoing, including one for men with prostate cancer [128-130]. A phase I study, the first to evaluate venetoclax for solid tumors, showed promising clinical activity in combination with tamoxifen for estrogen receptor (ER) and BCL-2-positive breast cancer, although a subsequent phase II study showed no benefit from the addition of venetoclax to fulvestrant for patients with ER positive/HER2 negative breast cancer who had progressed on a CDK4/ 6 inhibitor $[131,132]$.

\subsection{Strategies for Selective BCL-XL and Dual BCL-XL/BCL-2 Targeting}

In contrast to hematological malignancies, solid tumors, including prostate cancer, are more dependent on BCL-XL and MCL-1 for cell survival [133-137]. BCL-XL is highly expressed in a variety of solid malignancies, and its overexpression is associated with tumor progression and treatment resistance, making it a promising therapeutic target $[138,139]$. Pre-clinical studies have revealed anti-tumor activity in response to BCL-XL inhibition across a range of solid tumor cell lines and xenograft models, predominantly in combination with other agents [135,140-146]. As such, efforts are ongoing to develop strategies to target BCL-XL, which can circumvent on-target thrombocytopenia. ABBV-155 is an antibody drug conjugate linking a BCL-XL inhibitor with an anti-B7H3 antibody, thereby specifically targeting B7H3-expressing cancer cells and minimizing platelet destruction. A first-inhuman study has shown anti-cancer activity and tolerable toxicity for advanced solid 
tumors, in combination with paclitaxel, and the expansion phase is ongoing [147]. Another approach to diminish on-target toxicity is to use proteolysis targeting chimera (PROTAC) technology that targets a protein for degradation, and therefore does not need to directly inhibit protein activity. PROTACs are bivalent small molecules composed of two ligands; one able to bind a target protein and the other able to recruit an E3-ligase, resulting in ubiquitination and degradation of the protein via the proteasome. DT2216 is a PROTAC that targets BCL-XL to the Von Hippel-Lindau (VHL) E3-ligase, and, because there is limited expression in platelets, it has been shown to reduce on-target thrombocytopenia in mouse models, with a first-in-human study ongoing [148,149]. Interestingly, DT2216 has been shown to induce apoptosis in tumor-infiltrating regulatory T-cells, and activate tumor infiltrating CD8+ cells, resulting in suppression of tumor growth in immunocompetent, but not-immunodeficient, mouse models, indicating that targeting BCL-XL may be a promising strategy in cancer immunotherapy [150].

AZD0466, a dual BCL-2/BCL-XL inhibitor (AZD4320) conjugated to a PEGylated polylysine dendrimer, has been developed to optimize drug release rate and achieve maximal therapeutic index in terms of efficacy and tolerability. It is currently being evaluated in a phase I clinical trial for patients with advanced hematological or solid tumors [151,152]. Palcitoclax (APG-1252), a novel dual BCL-2/BCL-XL inhibitor, has also been designed to reduce platelet toxicity, and a ' $3+3$ ' design phase 1 escalation study revealed favorable toxicity and anti-cancer activity with 3 out of 36 evaluable patients achieving a partial response, including in one patient with neuroendocrine prostate cancer [153].

\subsection{Efforts to Target MCL-1}

Developing high-affinity inhibitors of MCL-1 has proven more challenging than for BCL-2 and BCL-XL, although several novel compounds have recently entered first-inhuman studies. A wide range of malignancies rely on MCL-1 for survival, and MCL-1 is one of the most frequently amplified genes in human cancer [137]. Knockdown of MCL-1, using short hairpin RNA, resulted in a more pronounced reduction in proliferation in MCL-1 amplified cell lines compared to non-amplified controls, indicating the functional relevance of this aberration [137]. In a range of hematological and solid cancers, MCL-1 has been implicated in tumor formation, cell survival, and treatment resistance, including resistance to BCL-XL and BCL-2 targeting [137,154-161]. The majority of pre-clinical studies have been conducted in hematological cancers, where a number of MCL-1 inhibitors have shown promising activity [162-166]. For example, MCL-1 inhibition led to significant induction of apoptosis in primary human multiple myeloma samples and amplification of 1q21 (containing MCL-1), which occurs in around $40 \%$ of newly diagnosed disease, correlated with sensitivity [167]. With respect to solid tumors, MCL-1 inhibition was effective in a subset of SCLC cell lines with high MCL-1 and low BCL-XL expression, including in a patient-derived cell line xenograft model in vivo [168]. In non-small cell lung cancer, genomic gains in $M C L-1$ occur with high frequency during tumor evolution, and tumor progression in transgenic mice was delayed with genetic or pharmacological inhibition of MCL-1 [169]. Pre-clinical anti-cancer activity has also been reported, primarily in combination with other therapeutics, in melanoma, breast, and colorectal cancer [161,170-172].

MCL-1 inhibitors under evaluation in early phase clinical trials include AMG-176, AMG-397, AZD-5991, S64315, ABBV-567, and PRT1419 [162-166]. Preliminary phase I data for AMG-176 suggested the drug may have acceptable toxicity, but its development, along with that of AMG-397, has been halted due to concerns regarding cardiac toxicity [173]. MCL-1 plays a critical role in normal physiology, including cardiomyocyte mitochondrial homeostasis, and MCL-1 knockout in mice induces fatal cardiomyopathy, highlighting the challenge of identifying a therapeutic window for this target $[174,175]$. Clinical evaluation of AZD-5991, S64315, and ABBV-567 is ongoing in hematological malignancies, and PRT1419 is also being evaluated in advanced solid malignancies. It remains to be seen whether novel drug delivery technologies, such as antibody drug conjugates and PROTACs, 
will be required to reduce dose limiting toxicities of MCL-1 inhibition, similar to how they are being evaluated for targeting BCL-XL.

\section{Evasion of Apoptosis in Prostate Cancer and Resistance to Established Therapies}

Deregulation and circumvention of apoptosis contributes to prostate cancer tumorigenesis, progression, and therapeutic resistance (Figure 2).

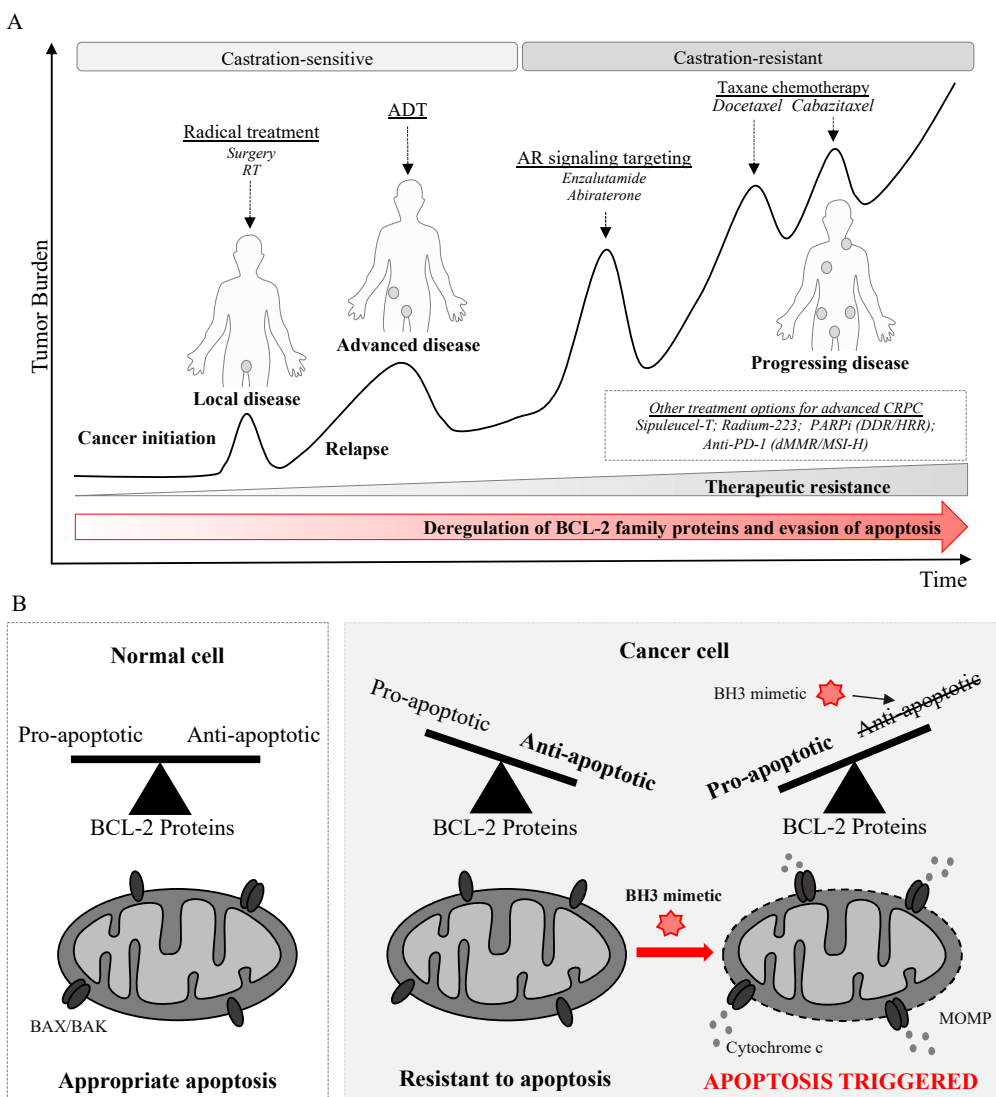

Figure 2. Evasion of apoptosis drives tumorigenesis, progression and therapeutic resistance in prostate cancer providing rationale for targeting anti-apoptotic BCL-2 proteins with $\mathrm{BH} 3$ mimetics. (A). An example of prostate cancer progression and treatment. Three-quarters of men are diagnosed with localized disease and can be treated with curative intent (prostatectomy or radiotherapy). However, an increasing percentage of men are being diagnosed with de novo metastatic disease and relapse occurs in 20 to $50 \%$ after radical treatment for early-stage disease. Most advanced prostate cancers respond to androgen deprivation therapy (ADT) but they inevitably progress from castration-sensitive to castration-resistant prostate cancer (CRPC). Approved therapies for advanced CRPC include androgen receptor (AR) signaling targeting, taxane-based chemotherapy and radium223 but primary and acquired resistance is common. Tumors with aberrations in homologous recombination repair (HRR) and DNA damage response (DDR) genes can be treated with Poly(ADPribose) polymerase (PARP) inhibitors and anti-PD-1 therapy can be used for defective mismatch repair (dMMR) or microsatellite instability-high (MSI-H) disease. Treatment sequence can vary considerably between patients depending on the nature of disease; AR signaling targeting and docetaxel can be also used for castration-sensitive disease. (B). The balance of pro- and anti-apoptotic BCL-2 proteins is critical in determining cell fate decisions. BCL-2 proteins are finely balanced in normal cells which can initiate apoptosis appropriately on exposure to cell death stimuli. In cancer cells, BCL-2 proteins are deregulated, increasing the threshold for apoptosis and promoting cell survival. $\mathrm{BH} 3$ mimetics bind to anti-apoptotic BCL-2 proteins, lowering the threshold and can trigger BAX/BAK homo-oligomerization, mitochondrial outer membrane permeabilization (MOMP), the release of cytochrome $\mathrm{c}$ and induction of apoptotic cell death. 


\subsection{BCL-2 Proteins in Prostate Cancer}

A number of immunohistological studies have shown high levels of MCL-1 and BCL-XL in prostate cancer, but BCL-2 appears to be expressed at lower levels, with more interstudy variability [47,176-184]. Published in 1996, Krajewska and colleagues were the first to undertake a comprehensive immunohistochemical analysis of the three major anti-apoptotic BCL-2 proteins in prostate cancer [177]. Immunohistochemistry for BCL-2, BCL-XL, and MCL-1 was undertaken for 64 cases of prostate adenocarcinoma, including eight bone and eight lymph node metastases. A total of 24 cases of prostatic intraepithelial neoplasia (PIN), largely accepted as a precursor lesion to invasive adenocarcinoma, were also analyzed. Lesions were defined as positive if at least $1 \%$ of tumor cells expressed the protein of interest. BCL-2 was positive in $25 \%$ of adenocarcinomas, with increasing frequency in high grade tumors and nodal metastases [177]. Conversely, a recent study using same patient matched samples showed no significant change in BCL-2 levels between CSPC and CRPC [185]. BCL-XL was found in all adenocarcinoma samples, with a higher immunointensity and percentage of positive cells in high grade primary tumors and metastases, compared to PIN and low grade tumors. MCL- 1 was detected in $81 \%$ of adenocarcinomas, compared to $38 \%$ of PIN cases, with an increasing percentage of positive cells in high grade tumors and metastases. The pro-apoptotic pore forming 'effector' BAX was detected in all 88 samples, 86 of which contained $>25 \%$ of positive staining tumor cells, suggesting that the majority of prostate cancers may still have the core machinery to undergo apoptosis if the apoptotic threshold is breached [177].

In another study, a post-mortem analysis of 185 metastatic lesions from 44 patients with heavily pre-treated metastatic prostate cancer revealed high levels of anti-apoptotic proteins, albeit with significant intra-patient heterogeneity between bone and soft tissue metastases [186]. In addition, pro-apoptotic BH3-only proteins have been implicated in prostate cancer, a topic which has been reviewed extensively elsewhere [187]. In summary, immunohistochemical evidence suggests that BCL-2 proteins play an important role in prostate cancer progression as the tumor becomes more resistant to cell death stimuli. Further studies with matched same patient diagnostic and metastatic sample analysis are required to confirm these findings and elucidate when these changes occur during tumor evolution. This will be important in determining the clinical translatability of targeting these proteins in advanced prostate cancer, although, as discussed, changes in BCL-2 proteins are dynamic, and this cannot be evaluated with immunohistochemical studies.

\subsection{Resistance to Established Therapies}

Established therapies for prostate cancer enact their therapeutic activity, to some extent, by the induction of apoptosis, and several studies have suggested that BCL-2 proteins play an important role in therapeutic resistance.

\subsubsection{Resistance to ADT}

The majority of advanced prostate cancers initially respond to ADT, though they inevitably develop into CRPC, with poor prognosis. As such, the development of strategies to prevent and treat lethal CRPC remains of high clinical importance. A number of immunohistochemical and functional studies have associated anti-apoptotic proteins with castration resistance, with most data focusing on BCL-2 [47,49,178,188-191]. In the hormone sensitive $\mathrm{LNCaP}$ prostate cancer cell line model, upregulation of BCL-2 is required for progression from an androgen-dependent to androgen-independent state, and overexpression of BCL-2 confers resistance to androgen depletion, protecting cells against apoptosis $[49,51,192]$. Similarly, upregulation of BCL-2 mRNA and protein expression was observed in LNCaP, LAPC4, and LAPC9 CRPC xenograft models with acquired resistance to ADT, aligning with previous data that androgens suppress BCL-2 expression [191,193]. Importantly, the same was not observed in a $\mathrm{VCaP}$ xenograft model, highlighting the inherent diversity of resistance mechanisms, the challenges of inter- and intra-patient heterogeneity, and the importance of patient selection for therapeutics [191]. MCL-1 has also been implicated in re- 
sistance to ADT, and is upregulated in androgen deprived prostate cancer cells, preventing the induction of apoptosis [188]. Furthermore, high BCL-XL expression has been associated with poor prognosis and the development of CRPC [47]. The pro-apoptotic pore forming 'effectors', BAX and BAK, are expressed at higher levels in localized prostate cancer compared to CRPC, suggesting their downregulation may be associated with resistance to ADT; however, the study did not include matched same patient CSPC and CRPC samples [178].

\subsubsection{Resistance to AR Signaling Inhibition}

Although the introduction of multiple agents that potently target the AR signaling axis (including abiraterone, enzalutamide and apalutamide) has improved outcomes for men with advanced prostate cancer, primary and acquired resistance remains common. Potent AR signaling inhibition has, in part, been shown to work via the induction of apoptosis, and BCL-2 is both induced by enzalutamide treatment and upregulated in castration resistant models with primary or acquired resistance to enzalutamide [191,194-196]. However, an analysis of same patient diagnostic and CRPC samples, from 20 patients with resistance to AR signaling axis targeting (7 of which had enzalutamide), showed no significant difference in BCL-2 protein levels [185].

Established resistance mechanisms that induce AR reactivation include $A R$ amplification, $A R$ mutation, increased AR ligand availability, and the generation of constitutively active AR splice variants; however, a subset of tumors are able to progress without relying on ARs to proliferate, termed AR pathway-independent prostate cancer [12]. Typically, this has been associated with small cell/neuroendocrine trans-differentiation with loss of AR expression, and evidence suggests that BCL-2 is highly upregulated in small cell neuroendocrine prostate cancer, compared to AR positive disease [197]. Furthermore, mounting data suggests that resistance to AR targeting can occur via an AR 'indifferent' state, where AR remains expressed but is not relied upon for cell proliferation [198-201]. Interestingly, two cell line models developed with acquired resistance to AR targeting, with AR indifference, were shown to have upregulation of MCL-1 and increased resistance to taxane chemotherapy [48].

\subsubsection{Resistance to Chemotherapy}

Targeting microtubules with taxane-based chemotherapy has been a mainstay of treatment for advanced prostate cancer since the approval of docetaxel for advanced CRPC in 2004 [15]. Subsequent studies have shown increased benefit when used earlier in the disease course for advanced CSPC [202]. Ten years ago, cabazitaxel was introduced as a second-line taxane chemotherapy for patients who had progressed on or after docetaxel [17]. Although taxane-based chemotherapy has improved outcomes for men with this lethal disease, primary and acquired resistance is common, and the survival advantage is modest $[15,17,27]$. As with hormonal treatment, taxane chemotherapy is postulated to, at least to some extent, exert its therapeutic benefit by inducing apoptosis, and elevated serum caspase-cleaved cytokeratin levels are observed in men treated with docetaxel for CRPC [40,203-205]. Microtubule targeting agents, including taxanes, prolong mitosis and promote apoptosis via degradation of MCL-1 [206]. MCL-1 has also been shown to protect prostate cancer cells from chemotherapy-induced DNA damage and cell death [53]. In addition, downregulation of anti-apoptotic BCL-XL in LNCaP and PC-3 prostate cancer cells increases sensitivity to multiple chemotherapeutic agents, whereas overexpression of BCL-XL is cytoprotective [52]. Conversely, high BCL-2 expression has been associated with improved outcome in men treated with taxane chemotherapy for CRPC, and is downregulated in response to docetaxel [178,207]. Taxanes are known to induce phosphorylation of BCL-2, reducing its anti-apoptotic function, which may explain this observation $[178,208]$. BCL-2 proteins have also been implicated in resistance to radiotherapy in prostate cancer, and an elevated BCL-2/BAX ratio is associated with radioresistance $[209,210]$.

In conclusion, deregulation of the intrinsic apoptosis machinery contributes to the development of CRPC and resistance to established therapies, suggesting that the utilization 
of therapies to target this pathway and breach the apoptotic threshold is an attractive strategy to treat this lethal disease.

\section{Targeting the Intrinsic Apoptosis Pathway in Prostate Cancer with BH3 Mimetics}

Inhibiting the three major anti-apoptotic proteins (BCL-2, BCL-XL, and MCL-1) is highly effective in driving apoptotic cell death; however, this is unlikely to be feasible in the clinic as significant toxicities are expected [211-213]. In fact, prior to the development of BH3 mimetics with high specificity, 'pan-BH3 mimetics' with broad engagement of multiple anti-apoptotic BCL-2 proteins were evaluated in pre-clinical studies, with promising results, including in prostate cancer $[188,214,215]$. However, these agents have lower affinity and specificity for their targets. The pan-BCL-2 inhibitor AT-101 was evaluated in early phase clinical trials for prostate cancer, but off-target gastrointestinal toxicities were dose limiting, and there was no significant anti-cancer activity [104,216,217]. As discussed, in view of this, these agents are no longer being evaluated in clinical trials, and have been superseded by highly selective BH3 mimetics with higher affinity and fewer off target effects.

Although a proportion of prostate cancers with significant addiction to a specific antiapoptotic protein may respond to a single agent $\mathrm{BH} 3$ mimetic, it is likely that combination therapies will be needed to lower the apoptotic threshold and increase the response rate. As with other solid malignancies, BCL-XL and MCL-1 appear to be more important than BCL-2 for cell survival in prostate cancer, although it is likely there is significant inter- and intrapatient heterogeneity [186,211]. As discussed, engagement of intrinsic apoptosis machinery is implicated in the efficacy of, and resistance to, many established therapies in prostate cancer, including ADT, AR signaling axis targeting, and chemotherapy (Figure 2). In this space, several pre-clinical studies have shown additional efficacy when these treatments are combined with $\mathrm{BH} 3$ mimetics.

Using LNCaP, C4-2, and 22Rv1 prostate cancer cells, synergism has been shown between enzalutamide and a range of $\mathrm{BH} 3$ mimetics with the induction of apoptosis [196]. Predictably, there were discrepancies in the efficacy of different combinations between the cell lines, signifying the importance of identifying predictive biomarkers to enrich response. Synergism between enzalutamide and navitoclax (BCL-2/BCL-XL/BCL-W inhibitor) was observed in all three cell lines, with the most marked effect in LNCaP cells, which also showed moderate sensitization with the addition of venetoclax (BCL-2 inhibitor). In contrast, $22 \mathrm{Rv} 1$ cells were most sensitive to the addition of A-1210477, an MCL-1 inhibitor [196]. In another study, the combination of enzalutamide and navitoclax (ABT-263) increased sensitivity in both enzalutamide-sensitive and (primary and acquired) -resistant prostate cancer cells, with elevated proteasomal degradation of AR and AR splice variant 7 (AR-V7) [218]. In vivo activity was also observed when 22Rv1 cell line mouse xenografts, which have primary resistance to enzalutamide, were treated with the combination of enzalutamide and navitoclax [218].

In keeping with elevated BCL-2 dependence with AR inhibition, in another study, venetoclax (BCL-2 inhibitor) was one of two agents used to specifically target enzalutamide resistant cells in a large-scale pharmacology screen [185]. The authors, and others, have validated these findings and shown enhanced anti-tumor activity and delayed resistance with the addition of venetoclax to enzalutamide in LNCaP derived CRPC AR-positive mouse xenograft models, suggesting this combination could be used to prevent and treat enzalutamide resistant CRPC [191]. In light of these findings, this combination is currently being evaluated in a phase Ib/II clinical trial for men with metastatic CRPC (NCT03751436). In contrast, when evaluating the AR negative LAPC9 CRPC model which has primary resistance to enzalutamide, in vivo anti-tumor activity was seen with single agent venetoclax, but there was no additional benefit with the addition of enzalutamide in organoid studies [191]. To our knowledge, NCT03751436 is the only clinical trial currently evaluating a selective $\mathrm{BH} 3$ mimetic specifically for prostate cancer. A phase Ib/II clinical trial assessing the combination of navitoclax and abiraterone, with or without hydroxychloroquine, was initiated in 2013 for men with metastatic CRPC, but was later terminated, as the inves- 
tigator left the organization with insufficient data to assess outcome (ClinicalTrials.gov, NCT01828476).

De novo small-cell neuroendocrine prostate cancer (SCNPC) is extremely rare, accounting for $<1 \%$ of prostate cancer at diagnosis [219]. However, as discussed, under potent AR signaling blockade, lineage plasticity and trans-differentiation from AR positive adenocarcinoma to an AR negative small cell/neuroendocrine phenotype occur in a subset of tumors. These tumors respond poorly to conventional therapies and are associated with poor prognosis. In keeping with upregulation of BCL-2 in small cell tumors, venetoclax (BCL-2 inhibitor) was shown to be more effective in SCNPC cells compared to AR-positive lines [197]. The authors subsequently treated five SCNPC patient-derived xenograft models with high expression of BCL-2 with navitoclax (BCL-2/BCL-XL/BCL-W inhibitor), observing two responses.

With respect to synergy with chemotherapy, navitoclax (ABT-263) sensitized PC3 prostate cancer cells to docetaxel in vitro and in vivo, with the predominant impact through inhibition of BCL-XL [220]. Similarly, navitoclax and ABT-737, the predecessor of navitoclax, have been shown to increase apoptotic cell death in LNCaP prostate cancer cells in combination with taxane-based chemotherapy (docetaxel and paclitaxel) [221,222]. Additionally, direct and indirect knockdown of MCL-1 has been shown to sensitize prostate cancer cells to anti-mitotic agents, including docetaxel, suggesting that MCL-1 targeting may also synergize with chemotherapy $[53,223,224]$. Interestingly, BCL-2 inhibition, with venetoclax or siRNA, sensitizes taxane-resistant prostate cancer cells (PC3 and DU145) to cisplatin chemotherapy, with BCL-2 overexpression reversing this effect [207].

Along with the established therapies, a number of cell survival signaling pathways are known to influence the intrinsic apoptosis pathway in cancer, some of which are emerging as important targets in prostate cancer. For example, PI3K/AKT pathway activation contributes to proliferation, progression, and treatment resistance in prostate cancer. Genomic aberrations in the PI3K/AKT signaling pathway are common in primary prostate cancer, and enriched in advanced CRPC (approximately 20 and 50\% respectively) [225-227]. Pathway activation is most often seen as a result of PTEN loss, occurring in around $40 \%$ of advanced CRPC. PTEN negatively regulates PI3K/AKT signaling, and its loss is emerging as a predictive biomarker for AKT inhibition. Recently published, the IPATential150 phase III trial showed a significant improvement in radiographic progression-free survival with the combination of the AKT inhibitor ipatasertib and abiraterone, versus abiraterone alone, in men with PTEN loss advanced CRPC [34]. Importantly, AKT is able to promote cell survival by phosphorylating BAD and inhibiting its pro-apoptotic function, thereby increasing the apoptotic threshold $[196,228,229]$. In keeping with this, the combination of a BCL-XL inhibitor (A-1331852) with an AKT (ipatasertib) or pan-PI3K inhibitor (buparlisib) was synergistic in PTEN deficient PC3 and LNCaP prostate cancer cell lines [230]. PTEN proficient DU145 cells were resistant to the combination; however, it should be noted that DU145 cells have reduced sensitivity to BH3 mimetics, which may be accounted for by the absence of BAX expression [220,221].

In addition, the Ras/Raf/MEK/ERK pathway promotes cell survival and has been shown to inhibit apoptosis by multiple mechanisms, including phosphorylation of BAD, suppression of BIM expression, and stabilization of MCL-1 [231-233]. Aberrations in this pathway are infrequently found in prostate cancer, but do correlate with progression and treatment resistance, providing pre-clinical rationale for targeting this pathway in combination with BH3 mimetics in this subset of tumors $[234,235]$. Furthermore, several receptor tyrosine kinase inhibitors, including erlotinib, lapatinib, cabozantinib, and sorafenib have been shown to increase MCL-1 degradation, resulting in robust apoptotic cell death when combined with ABT-737 in prostate cancer cells, both in vitro and in vivo. Interestingly, this was independent of the PI3K/AKT and Ras/Raf/MEK/ERK pathways, and instead driven by the integrated stress response and NOXA-dependent MCL-1 degradation, which was mediated by the E3 ubiquitin ligase MARCH5 [211,236]. These therapies may target MCL-1 more selectively in tumor cells, and could help circumvent the toxicity expected with direct 
MCL-1 inhibition in combination with BCL-XL/BCL-2 targeting. Aside from BH3 mimetics, there are limited data for other agents directly targeting the intrinsic apoptosis pathway in prostate cancer, and further studies are warranted. IAP family protein levels, including survivin, are known to be elevated in prostate cancer, and targeting survivin resulted in tumor regression in PC-3 cell line xenograft mouse models $[237,238]$.

\section{Future Perspectives and Conclusions}

The eradication of prostate cancer cells by triggering the intrinsic apoptosis pathway is a promising new therapeutic strategy for prostate cancer. Driving apoptotic cell death, as opposed to growth inhibition, should reduce the chances of cancer cell adaptation and therapeutic resistance. Many of the established therapies for prostate cancer are known to lower the apoptotic threshold, providing strong biological rationale for combining these agents with BH3 mimetics. In addition, other cell survival pathways, such as PI3K/AKT signaling, are becoming important targets in prostate cancer, and drive cell survival, to some extent, by modulating intrinsic apoptotic machinery. BH3 mimetics have shown strong anti-cancer activity in hematological malignancies, and venetoclax, a BCL-2 inhibitor, is now approved for CLL and AML. Solid tumors, including prostate cancer, appear to be more reliant on BCL-XL and MCL-1 for cell survival. Efforts to target these proteins are ongoing, although the development of drug-related adverse events, including dose-limiting thrombocytopenia and cardiac toxicity, has slowed their clinical development. Novel drug delivery technologies, such as antibody drug conjugates (e.g., targeting PSMA or B7H3) or PROTACs, may help mitigate toxicities and induce cancer-specific cell death. Early-phase clinical trials evaluating $\mathrm{BH} 3$ mimetics are ongoing, though only one study is specifically focused on prostate cancer. Although there is good pre-clinical rationale for the use of these agents in prostate cancer, well designed biomarker-driven clinical trials are required to evaluate whether these strategies will improve outcomes for men with this lethal disease. In this space, the use of molecular characterization and the identification of tumors with a dependency on the intrinsic apoptosis pathway will be critical to the successful clinical implementation of these agents.

Author Contributions: Conceptualization, D.W., J.M.J.-V., A.P., A.V., S.P.B., J.S.d.B. and A.S.; resources, S.P.B., J.S.d.B. and A.S.; writing-original draft preparation, D.W., J.M.J.-V. and A.S.; writingreview and editing, D.W., J.M.J.-V., A.P., A.V., S.P.B., J.S.d.B. and A.S.; supervision, S.P.B., J.S.d.B. and A.S.; funding acquisition, S.P.B., J.S.d.B. and A.S. All authors have read and agreed to the published version of the manuscript.

Funding: D.W. was supported by a CRUK Clinical Research Training Fellowship. J.M.J.-V. was supported by a PCUK Travelling Prize Fellowship (TLD-PF19-006). A.V. was supported by the Department of Defense and an American Society of Clinical Oncology Young Investigator Award. Work in the S.P.B. laboratory was supported by research funding from the NIH (R01 CA262536) and a Prostate Cancer Foundation Challenge Award. Work in the J.S.d.B. laboratory was supported by research funding from Prostate Cancer UK, the Movember Foundation through the London Movember Centre of Excellence (CEO13_2-002), the Prostrate Cancer Foundation, Cancer Research UK (Centre Programme grant), Experimental Cancer Medicine Centre grant funding from Cancer Research UK and the Department of Health, and Biomedical Research Centre funding to the Royal Marsden. J.S.d.B. is a National Institute for Health Research (NIHR) Senior Investigator. Work in the A.S. laboratory was supported by research funding from the Wellcome Trust, the Prostrate Cancer Foundation, and the NIHR Biomedical Research Centre. The views expressed in this article are those of the author(s), and not necessarily those of the NHS, the NIHR, or the Department of Health.

Conflicts of Interest: D.W., J.M.J.-V. and A.P. are employees of the ICR, which has a commercial interest in abiraterone, PARP inhibition in DNA repair-defective cancers, and PI3K/AKT pathway inhibitors (no personal income). A.V. has no conflicts. S.P.B. has no conflicts. J.S.d.B. has served on advisory boards and received fees from many companies, including Amgen, Astra Zeneca, Astellas, Bayer, Bioxcel Therapeutics, Boehringer Ingelheim, Cellcentric, Daiichi, Eisai, Genentech/Roche, Genmab, GSK, Harpoon, ImCheck Therapeutics, Janssen, Merck Serono, Merck Sharp \& Dohme, Menarini/Silicon Biosystems, Orion, Pfizer, Qiagen, Sanofi Aventis, Sierra Oncology, Taiho, Terumo, 
and Vertex Pharmaceuticals. He is an employee of the ICR, which has received funding or other support for his research work from AstraZeneca, Astellas, Bayer, Cellcentric, Daiichi, Genentech, Genmab, GSK, Janssen, Merck Serono, MSD, Menarini/Silicon Biosystems, Orion, Sanofi Aventis, Sierra Oncology, Taiho, Pfizer, and Vertex, and which has a commercial interest in abiraterone, PARP inhibition in DNA repair defective cancers, and PI3K/AKT pathway inhibitors (no personal income). J.S.d.B. was named as an inventor, with no financial interest, for patent $8,822,438$, submitted by Janssen, that covers the use of abiraterone acetate with corticosteroids. J.S.d.B. has been the CI/PI of many industry-sponsored clinical trials. A.S. is an employee of the ICR, which has a commercial interest in abiraterone, PARP inhibition in DNA repair defective cancers, and PI3K/AKT pathway inhibitors (no personal income). A.S. has received travel support from Sanofi and Roche-Genentech, and speaker honoraria from Astellas Pharma. A.S. has been the CI/PI of industry-sponsored clinical trials.

\section{References}

1. Siegel, R.L.; Miller, K.D.; Jemal, A. Cancer statistics, 2020. CA Cancer J. Clin. 2020, 70, 7-30. [CrossRef]

2. Glocal Cancer Observatory. Available online: https://gco.iarc.fr/ (accessed on 23 March 2021).

3. Siegel, D.A.; O'Neil, M.E.; Richards, T.B.; Dowling, N.F.; Weir, H.K. Prostate cancer incidence and survival, by stage and race/ethnicity-United States, 2001-2017. MMWR Morb. Mortal. Wkly. Rep. 2020, 69, 1473-1480. [CrossRef]

4. Stephenson, A.J.; Scardino, P.T.; Eastham, J.A.; Bianco, F.J., Jr.; Dotan, Z.A.; Fearn, P.A.; Kattan, M.W. Preoperative nomogram predicting the 10-year probability of prostate cancer recurrence after radical prostatectomy. J. Natl. Cancer Inst. 2006, 98, 715-717. [CrossRef]

5. Hull, G.W.; Rabbani, F.; Abbas, F.; Wheeler, T.M.; Kattan, M.W.; Scardino, P.T. Cancer control with radical prostatectomy alone in 1000 consecutive patients. J. Urol. 2002, 167, 528-534. [CrossRef]

6. Kupelian, P.; Katcher, J.; Levin, H.; Zippe, C.; Klein, E. Correlation of clinical and pathologic factors with rising prostate-specific antigen profiles after radical prostatectomy alone for clinically localized prostate cancer. Urology 1996, 48, 249-260. [CrossRef]

7. Kupelian, P.A.; Mahadevan, A.; Reddy, C.A.; Reuther, A.M.; Klein, E.A. Use of different definitions of biochemical failure after external beam radiotherapy changes conclusions about relative treatment efficacy for localized prostate cancer. Urology 2006, 68, 593-598. [CrossRef] [PubMed]

8. Wilding, G. The importance of steroid hormones in prostate cancer. Cancer Surv. 1992, 14, 113-130. [PubMed]

9. Sartor, O.; de Bono, J.S. Metastatic prostate cancer. N. Engl. J. Med. 2018, 378, 1653-1654. [CrossRef] [PubMed]

10. Huggins, C.; Hodges, C.V. Studies on prostatic cancer: I. The effect of castration, of estrogen and of androgen injection on serum phosphatases in metastatic carcinoma of the prostate. Cancer Res. 1941, 1, 293-297.

11. Huggins, C.; Stevens, R.E.; Hodges, C.V. Studies on prostatic cancer: II. The effects of castration on advanced carcinoma of the prostate gland. Arch. Surg. 1941, 43, 645-657. [CrossRef]

12. Westaby, D.; Maza, M.; Paschalis, A.; Jimenez-Vacas, J.M.; Welti, J.; de Bono, J.; Sharp, A. A new old target: Androgen receptor signaling and advanced prostate cancer. Annu. Rev. Pharmacol. Toxicol. 2021. [CrossRef] [PubMed]

13. Mehtala, J.; Zong, J.; Vassilev, Z.; Brobert, G.; Gabarro, M.S.; Stattin, P.; Khanfir, H. Overall survival and second primary malignancies in men with metastatic prostate cancer. PLoS ONE 2020, 15, e0227552. [CrossRef]

14. Moreira, D.M.; Howard, L.E.; Sourbeer, K.N.; Amarasekara, H.S.; Chow, L.C.; Cockrell, D.C.; Pratson, C.L.; Hanyok, B.T.; Aronson, W.J.; Kane, C.J.; et al. Predicting time from metastasis to overall survival in castration-resistant prostate cancer: Results from SEARCH. Clin. Genitourin. Cancer 2017, 15, 60-66. [CrossRef] [PubMed]

15. Tannock, I.F.; de Wit, R.; Berry, W.R.; Horti, J.; Pluzanska, A.; Chi, K.N.; Oudard, S.; Theodore, C.; James, N.D.; Turesson, I.; et al. Docetaxel plus prednisone or mitoxantrone plus prednisone for advanced prostate cancer. N. Engl. J. Med. 2004, 351, 1502-1512. [CrossRef] [PubMed]

16. Petrylak, D.P.; Tangen, C.M.; Hussain, M.H.; Lara, P.N., Jr.; Jones, J.A.; Taplin, M.E.; Burch, P.A.; Berry, D.; Moinpour, C.; Kohli, M.; et al. Docetaxel and estramustine compared with mitoxantrone and prednisone for advanced refractory prostate cancer. N. Engl. J. Med. 2004, 351, 1513-1520. [CrossRef]

17. De Bono, J.S.; Oudard, S.; Ozguroglu, M.; Hansen, S.; Machiels, J.P.; Kocak, I.; Gravis, G.; Bodrogi, I.; Mackenzie, M.J.; Shen, L.; et al. Prednisone plus cabazitaxel or mitoxantrone for metastatic castration-resistant prostate cancer progressing after docetaxel treatment: A randomised open-label trial. Lancet 2010, 376, 1147-1154. [CrossRef]

18. Fizazi, K.; Scher, H.I.; Molina, A.; Logothetis, C.J.; Chi, K.N.; Jones, R.J.; Staffurth, J.N.; North, S.; Vogelzang, N.J.; Saad, F.; et al. Abiraterone acetate for treatment of metastatic castration-resistant prostate cancer: Final overall survival analysis of the COU-AA-301 randomised, double-blind, placebo-controlled phase 3 study. Lancet Oncol. 2012, 13, 983-992. [CrossRef]

19. Ryan, C.J.; Smith, M.R.; Fizazi, K.; Saad, F.; Mulders, P.F.; Sternberg, C.N.; Miller, K.; Logothetis, C.J.; Shore, N.D.; Small, E.J.; et al. Abiraterone acetate plus prednisone versus placebo plus prednisone in chemotherapy-naive men with metastatic castrationresistant prostate cancer (COU-AA-302): Final overall survival analysis of a randomised, double-blind, placebo-controlled phase 3 study. Lancet Oncol. 2015, 16, 152-160. [CrossRef]

20. Scher, H.I.; Fizazi, K.; Saad, F.; Taplin, M.E.; Sternberg, C.N.; Miller, K.; de Wit, R.; Mulders, P.; Chi, K.N.; Shore, N.D.; et al. Increased survival with enzalutamide in prostate cancer after chemotherapy. N. Engl. J. Med. 2012, 367, 1187-1197. [CrossRef] [PubMed] 
21. Beer, T.M.; Armstrong, A.J.; Rathkopf, D.; Loriot, Y.; Sternberg, C.N.; Higano, C.S.; Iversen, P.; Evans, C.P.; Kim, C.S.; Kimura, G.; et al. Enzalutamide in men with chemotherapy-naive metastatic castration-resistant prostate cancer: Extended analysis of the phase 3 PREVAIL study. Eur. Urol. 2017, 71, 151-154. [CrossRef]

22. Kantoff, P.W.; Higano, C.S.; Shore, N.D.; Berger, E.R.; Small, E.J.; Penson, D.F.; Redfern, C.H.; Ferrari, A.C.; Dreicer, R.; Sims, R.B.; et al. Sipuleucel-T immunotherapy for castration-resistant prostate cancer. N. Engl. J. Med. 2010, 363, 411-422. [CrossRef]

23. Parker, C.; Nilsson, S.; Heinrich, D.; Helle, S.I.; O'Sullivan, J.M.; Fossa, S.D.; Chodacki, A.; Wiechno, P.; Logue, J.; Seke, M.; et al. Alpha emitter radium-223 and survival in metastatic prostate cancer. N. Engl. J. Med. 2013, 369, 213-223. [CrossRef] [PubMed]

24. Armstrong, A.J.; Szmulewitz, R.Z.; Petrylak, D.P.; Holzbeierlein, J.; Villers, A.; Azad, A.; Alcaraz, A.; Alekseev, B.; Iguchi, T.; Shore, N.D.; et al. ARCHES: A randomized, phase III study of androgen deprivation therapy with enzalutamide or placebo in men with metastatic hormone-sensitive prostate cancer. J. Clin. Oncol. 2019, 37, 2974-2986. [CrossRef]

25. Chi, K.N.; Agarwal, N.; Bjartell, A.; Chung, B.H.; Pereira de Santana Gomes, A.J.; Given, R.; Juarez Soto, A.; Merseburger, A.S.; Ozguroglu, M.; Uemura, H.; et al. Apalutamide for metastatic, castration-sensitive prostate cancer. N. Engl. J. Med. 2019, 381, 13-24. [CrossRef] [PubMed]

26. Davis, I.D.; Martin, A.J.; Stockler, M.R.; Begbie, S.; Chi, K.N.; Chowdhury, S.; Coskinas, X.; Frydenberg, M.; Hague, W.E.; Horvath, L.G.; et al. Enzalutamide with standard first-line therapy in metastatic prostate cancer. N. Engl. J. Med. 2019, 381, 121-131. [CrossRef]

27. Tucci, M.; Bertaglia, V.; Vignani, F.; Buttigliero, C.; Fiori, C.; Porpiglia, F.; Scagliotti, G.V.; Di Maio, M. Addition of docetaxel to androgen deprivation therapy for patients with hormone-sensitive metastatic prostate cancer: A systematic review and meta-analysis. Eur. Urol. 2016, 69, 563-573. [CrossRef] [PubMed]

28. Fizazi, K.; Tran, N.; Fein, L.; Matsubara, N.; Rodriguez-Antolin, A.; Alekseev, B.Y.; Özgüroglu, M.; Ye, D.; Feyerabend, S.; Protheroe, A.; et al. Abiraterone acetate plus prednisone in patients with newly diagnosed high-risk metastatic castrationsensitive prostate cancer (LATITUDE): Final overall survival analysis of a randomised, double-blind, phase 3 trial. Lancet Oncol. 2019, 20, 686-700. [CrossRef]

29. James, N.D.; De Bono, J.S.; Spears, M.R.; Clarke, N.W.; Mason, M.D.; Dearnaley, D.P.; Ritchie, A.W.; Amos, C.L.; Gilson, C.; Jones, R.J.; et al. Abiraterone for Prostate Cancer Not Previously Treated with Hormone Therapy. New Engl. J. Med. 2017, 377, 338-351. [CrossRef]

30. Bumbaca, B.; Li, W. Taxane resistance in castration-resistant prostate cancer: Mechanisms and therapeutic strategies. Acta Pharm. Sin. B 2018, 8, 518-529. [CrossRef]

31. Chen, C.D.; Welsbie, D.S.; Tran, C.; Baek, S.H.; Chen, R.; Vessella, R.; Rosenfeld, M.G.; Sawyers, C.L. Molecular determinants of resistance to antiandrogen therapy. Nat. Med. 2004, 10, 33-39. [CrossRef]

32. Abida, W.; Patnaik, A.; Campbell, D.; Shapiro, J.; Bryce, A.H.; McDermott, R.; Sautois, B.; Vogelzang, N.J.; Bambury, R.M.; Voog, E.; et al. Rucaparib in men with metastatic castration-resistant prostate cancer harboring a BRCA1 or BRCA2 gene alteration. J. Clin. Oncol. 2020, 38, 3763-3772. [CrossRef]

33. Mateo, J.; Carreira, S.; Sandhu, S.; Miranda, S.; Mossop, H.; Perez-Lopez, R.; Nava Rodrigues, D.; Robinson, D.; Omlin, A.; Tunariu, N.; et al. DNA-repair defects and olaparib in metastatic prostate cancer. N. Engl. J. Med. 2015, 373, 1697-1708. [CrossRef]

34. De Bono, J.S.; Bracarda, S.; Sternberg, C.N.; Chi, K.N.; Olmos, D.; Sandhu, S.; Massard, C.; Matsubara, N.; Alekseev, B.; Gafanov, R.; et al. LBA4 IPATential150: Phase III study of ipatasertib (ipat) plus abiraterone (abi) vs placebo (pbo) plus abi in metastatic castration-resistant prostate cancer (mCRPC). Ann. Oncol. 2020, 31, S1153-S1154. [CrossRef]

35. Le, D.T.; Durham, J.N.; Smith, K.N.; Wang, H.; Bartlett, B.R.; Aulakh, L.K.; Lu, S.; Kemberling, H.; Wilt, C.; Luber, B.S.; et al Mismatch repair deficiency predicts response of solid tumors to PD-1 blockade. Science 2017, 357, 409-413. [CrossRef] [PubMed]

36. Cristescu, R.; Mogg, R.; Ayers, M.; Albright, A.; Murphy, E.; Yearley, J.; Sher, X.; Liu, X.Q.; Lu, H.; Nebozhyn, M.; et al. Pan-tumor genomic biomarkers for PD-1 checkpoint blockade-based immunotherapy. Science 2018, 362. [CrossRef] [PubMed]

37. Sweat, S.D.; Pacelli, A.; Murphy, G.P.; Bostwick, D.G. Prostate-specific membrane antigen expression is greatest in prostate adenocarcinoma and lymph node metastases. Urology 1998, 52, 637-640. [CrossRef]

38. Silver, D.A.; Pellicer, I.; Fair, W.R.; Heston, W.D.; Cordon-Cardo, C. Prostate-specific membrane antigen expression in normal and malignant human tissues. Clin. Cancer Res. 1997, 3, 81-85.

39. Sartor, O.; de Bono, J.; Chi, K.N.; Fizazi, K.; Herrmann, K.; Rahbar, K.; Tagawa, S.T.; Nordquist, L.T.; Vaishampayan, N.; El-Haddad, G.; et al. Lutetium-177-PSMA-617 for metastatic castration-resistant prostate cancer. N. Engl. J. Med. 2021, 385, $1091-1103$. [CrossRef]

40. Kramer, G.; Schwarz, S.; Hagg, M.; Havelka, A.M.; Linder, S. Docetaxel induces apoptosis in hormone refractory prostate carcinomas during multiple treatment cycles. Br. J. Cancer 2006, 94, 1592-1598. [CrossRef]

41. Zhang, K.X.; Firus, J.; Prieur, B.; Jia, W.; Rennie, P.S. To die or to survive, a fatal question for the destiny of prostate cancer cells after androgen deprivation therapy. Cancers 2011, 3, 1498-1512. [CrossRef]

42. Westin, P.; Stattin, P.; Damber, J.E.; Bergh, A. Castration therapy rapidly induces apoptosis in a minority and decreases cell proliferation in a majority of human prostatic tumors. Am. J. Pathol. 1995, 146, 1368-1375. [PubMed]

43. Ohlson, N.; Wikstrom, P.; Stattin, P.; Bergh, A. Cell proliferation and apoptosis in prostate tumors and adjacent non-malignant prostate tissue in patients at different time-points after castration treatment. Prostate 2005, 62, 307-315. [CrossRef] 
44. Agus, D.B.; Cordon-Cardo, C.; Fox, W.; Drobnjak, M.; Koff, A.; Golde, D.W.; Scher, H.I. Prostate cancer cell cycle regulators: Response to androgen withdrawal and development of androgen independence. J. Natl. Cancer Inst. 1999, 91, 1869-1876. [CrossRef] [PubMed]

45. Burton, D.G.; Giribaldi, M.G.; Munoz, A.; Halvorsen, K.; Patel, A.; Jorda, M.; Perez-Stable, C.; Rai, P. Androgen deprivationinduced senescence promotes outgrowth of androgen-refractory prostate cancer cells. PLoS ONE 2013, 8, e68003. [CrossRef]

46. Carneiro, B.A.; El-Deiry, W.S. Targeting apoptosis in cancer therapy. Nat. Rev. Clin. Oncol. 2020, 17, 395-417. [CrossRef]

47. Castilla, C.; Congregado, B.; Chinchon, D.; Torrubia, F.J.; Japon, M.A.; Saez, C. Bcl-xL is overexpressed in hormone-resistant prostate cancer and promotes survival of LNCaP cells via interaction with proapoptotic Bak. Endocrinology 2006, 147, $4960-4967$. [CrossRef]

48. Handle, F.; Prekovic, S.; Helsen, C.; Van den Broeck, T.; Smeets, E.; Moris, L.; Eerlings, R.; Kharraz, S.E.; Urbanucci, A.; Mills, I.G.; et al. Drivers of AR indifferent anti-androgen resistance in prostate cancer cells. Sci. Rep. 2019, 9, 13786. [CrossRef]

49. Raffo, A.J.; Perlman, H.; Chen, M.W.; Day, M.L.; Streitman, J.S.; Buttyan, R. Overexpression of bcl-2 protects prostate cancer cells from apoptosis in vitro and confers resistance to androgen depletion in vivo. Cancer Res. 1995, 55, 4438-4445.

50. Kim, J.H.; Lee, H.; Shin, E.A.; Kim, D.H.; Choi, J.B.; Kim, S.H. Implications of Bcl-2 and its interplay with other molecules and signaling pathways in prostate cancer progression. Expert Opin. Ther. Targets 2017, 21, 911-920. [CrossRef] [PubMed]

51. Lin, Y.; Fukuchi, J.; Hiipakka, R.A.; Kokontis, J.M.; Xiang, J. Up-regulation of Bcl-2 is required for the progression of prostate cancer cells from an androgen-dependent to an androgen-independent growth stage. Cell Res. 2007, 17, 531-536. [CrossRef] [PubMed]

52. Lebedeva, I.; Rando, R.; Ojwang, J.; Cossum, P.; Stein, C.A. Bcl-xL in prostate cancer cells: Effects of overexpression and down-regulation on chemosensitivity. Cancer Res. 2000, 60, 6052-6060.

53. Reiner, T.; de Las Pozas, A.; Parrondo, R.; Palenzuela, D.; Cayuso, W.; Rai, P.; Perez-Stable, C. Mcl-1 protects prostate cancer cells from cell death mediated by chemotherapy-induced DNA damage. Oncoscience 2015, 2, 703-715. [CrossRef]

54. Danial, N.N.; Korsmeyer, S.J. Cell death: Critical control points. Cell 2004, 116, 205-219. [CrossRef]

55. Campbell, K.J.; Leung, H.Y. Evasion of cell death: A contributory factor in prostate cancer development and treatment resistance. Cancer Lett. 2021, 520, 213-221. [CrossRef] [PubMed]

56. Galluzzi, L.; Maiuri, M.C.; Vitale, I.; Zischka, H.; Castedo, M.; Zitvogel, L.; Kroemer, G. Cell death modalities: Classification and pathophysiological implications. Cell Death Differ. 2007, 14, 1237-1243. [CrossRef]

57. Galluzzi, L.; Vitale, I.; Aaronson, S.A.; Abrams, J.M.; Adam, D.; Agostinis, P.; Alnemri, E.S.; Altucci, L.; Amelio, I.; Andrews, D.W.; et al. Molecular mechanisms of cell death: Recommendations of the Nomenclature Committee on Cell Death 2018. Cell Death Differ. 2018, 25, 486-541. [CrossRef]

58. Galluzzi, L.; Bravo-San Pedro, J.M.; Kepp, O.; Kroemer, G. Regulated cell death and adaptive stress responses. Cell Mol. Life Sci. 2016, 73, 2405-2410. [CrossRef] [PubMed]

59. Galluzzi, L.; Bravo-San Pedro, J.M.; Vitale, I.; Aaronson, S.A.; Abrams, J.M.; Adam, D.; Alnemri, E.S.; Altucci, L.; Andrews, D.; Annicchiarico-Petruzzelli, M.; et al. Essential versus accessory aspects of cell death: Recommendations of the NCCD 2015. Cell Death Differ. 2015, 22, 58-73. [CrossRef] [PubMed]

60. Yatim, N.; Cullen, S.; Albert, M.L. Dying cells actively regulate adaptive immune responses. Nat. Rev. Immunol. 2017, 17, 262-275 [CrossRef]

61. Strasser, A.; Harris, A.W.; Huang, D.C.; Krammer, P.H.; Cory, S. Bcl-2 and Fas/APO-1 regulate distinct pathways to lymphocyte apoptosis. EMBO J. 1995, 14, 6136-6147. [CrossRef]

62. Barnhart, B.C.; Alappat, E.C.; Peter, M.E. The CD95 type I/type II model. Semin. Immunol. 2003, 15, 185-193. [CrossRef]

63. Ozoren, N.; El-Deiry, W.S. Defining characteristics of types I and II apoptotic cells in response to TRAIL. Neoplasia 2002, 4, 551-557. [CrossRef]

64. Li, H.; Zhu, H.; Xu, C.J.; Yuan, J. Cleavage of BID by caspase 8 mediates the mitochondrial damage in the Fas pathway of apoptosis. Cell 1998, 94, 491-501. [CrossRef]

65. Yin, X.M.; Wang, K.; Gross, A.; Zhao, Y.; Zinkel, S.; Klocke, B.; Roth, K.A.; Korsmeyer, S.J. Bid-deficient mice are resistant to Fas-induced hepatocellular apoptosis. Nature 1999, 400, 886-891. [CrossRef]

66. Wang, K.J.; Wang, K.Y.; Zhang, H.Z.; Meng, X.Y.; Chen, J.F.; Wang, P.; Jiang, J.H.; Ma, Q. Up-regulation of RIP3 alleviates prostate cancer progression by activation of RIP3/MLKL signaling pathway and induction of necroptosis. Front. Oncol. 2020, 10, 1720. [CrossRef]

67. Ghoochani, A.; Hsu, E.C.; Aslan, M.; Rice, M.A.; Nguyen, H.M.; Brooks, J.D.; Corey, E.; Paulmurugan, R.; Stoyanova, T. Ferroptosis inducers are a novel therapeutic approach for advanced prostate cancer. Cancer Res. 2021, 81, 1583-1594. [CrossRef]

68. Kale, J.; Osterlund, E.J.; Andrews, D.W. BCL-2 family proteins: Changing partners in the dance towards death. Cell Death Differ. 2018, 25, 65-80. [CrossRef]

69. Singh, R.; Letai, A.; Sarosiek, K. Regulation of apoptosis in health and disease: The balancing act of BCL-2 family proteins. Nat. Rev. Mol. Cell Biol. 2019, 20, 175-193. [CrossRef] [PubMed]

70. Ni Chonghaile, T.; Sarosiek, K.A.; Vo, T.T.; Ryan, J.A.; Tammareddi, A.; Moore Vdel, G.; Deng, J.; Anderson, K.C.; Richardson, P.; Tai, Y.T.; et al. Pretreatment mitochondrial priming correlates with clinical response to cytotoxic chemotherapy. Science 2011, 334, 1129-1133. [CrossRef]

71. Nakano, K.; Vousden, K.H. PUMA, a novel proapoptotic gene, is induced by p53. Mol. Cell 2001, 7, 683-694. [CrossRef] 
72. Oda, E.; Ohki, R.; Murasawa, H.; Nemoto, J.; Shibue, T.; Yamashita, T.; Tokino, T.; Taniguchi, T.; Tanaka, N. Noxa, a BH3-only member of the Bcl-2 family and candidate mediator of p53-induced apoptosis. Science 2000, 288, 1053-1058. [CrossRef] [PubMed]

73. Letai, A.; Bassik, M.C.; Walensky, L.D.; Sorcinelli, M.D.; Weiler, S.; Korsmeyer, S.J. Distinct BH3 domains either sensitize or activate mitochondrial apoptosis, serving as prototype cancer therapeutics. Cancer Cell 2002, 2, 183-192. [CrossRef]

74. Czabotar, P.E.; Lessene, G.; Strasser, A.; Adams, J.M. Control of apoptosis by the BCL-2 protein family: Implications for physiology and therapy. Nat. Rev. Mol. Cell Biol. 2014, 15, 49-63. [CrossRef]

75. Huang, K.; O’Neill, K.L.; Li, J.; Zhou, W.; Han, N.; Pang, X.; Wu, W.; Struble, L.; Borgstahl, G.; Liu, Z.; et al. BH3-only proteins target BCL-xL/MCL-1, not BAX/BAK, to initiate apoptosis. Cell Res. 2019, 29, 942-952. [CrossRef] [PubMed]

76. Iyer, S.; Uren, R.T.; Dengler, M.A.; Shi, M.X.; Uno, E.; Adams, J.M.; Dewson, G.; Kluck, R.M. Robust autoactivation for apoptosis by BAK but not BAX highlights BAK as an important therapeutic target. Cell Death Dis. 2020, 11, 268. [CrossRef] [PubMed]

77. Greaves, G.; Milani, M.; Butterworth, M.; Carter, R.J.; Byrne, D.P.; Eyers, P.A.; Luo, X.; Cohen, G.M.; Varadarajan, S. BH3-only proteins are dispensable for apoptosis induced by pharmacological inhibition of both MCL-1 and BCL-XL. Cell Death Differ. 2019, 26, 1037-1047. [CrossRef]

78. O'Neill, K.L.; Huang, K.; Zhang, J.; Chen, Y.; Luo, X. Inactivation of prosurvival Bcl-2 proteins activates Bax/Bak through the outer mitochondrial membrane. Genes Dev. 2016, 30, 973-988. [CrossRef]

79. Silke, J.; Meier, P. Inhibitor of apoptosis (IAP) proteins-modulators of cell death and inflammation. Cold Spring Harb. Perspect. Biol. 2013, 5, a008730. [CrossRef]

80. Marsden, V.S.; O'Connor, L.; O’Reilly, L.A.; Silke, J.; Metcalf, D.; Ekert, P.G.; Huang, D.C.; Cecconi, F.; Kuida, K.; Tomaselli, K.J.; et al. Apoptosis initiated by Bcl-2-regulated caspase activation independently of the cytochrome c/Apaf-1/caspase-9 apoptosome. Nature 2002, 419, 634-637. [CrossRef]

81. Ichim, G.; Lopez, J.; Ahmed, S.U.; Muthalagu, N.; Giampazolias, E.; Delgado, M.E.; Haller, M.; Riley, J.S.; Mason, S.M.; Athineos, D.; et al. Limited mitochondrial permeabilization causes DNA damage and genomic instability in the absence of cell death. Mol. Cell 2015, 57, 860-872. [CrossRef]

82. Sarosiek, K.A.; Fraser, C.; Muthalagu, N.; Bhola, P.D.; Chang, W.; McBrayer, S.K.; Cantlon, A.; Fisch, S.; Golomb-Mello, G.; Ryan, J.A.; et al. Developmental regulation of mitochondrial apoptosis by c-Myc governs age- and tissue-specific sensitivity to cancer therapeutics. Cancer Cell 2017, 31, 142-156. [CrossRef]

83. Madden, S.D.; Donovan, M.; Cotter, T.G. Key apoptosis regulating proteins are down-regulated during postnatal tissue development. Int. J. Dev. Biol. 2007, 51, 415-423. [CrossRef]

84. Lopez, J.; Tait, S.W. Mitochondrial apoptosis: Killing cancer using the enemy within. Br. J. Cancer 2015, 112, 957-962. [CrossRef]

85. Whitfield, J.R.; Beaulieu, M.E.; Soucek, L. Strategies to inhibit Myc and their clinical applicability. Front. Cell Dev. Biol. 2017, 5, 10. [CrossRef] [PubMed]

86. Bai, S.; Cao, S.; Jin, L.; Kobelski, M.; Schouest, B.; Wang, X.; Ungerleider, N.; Baddoo, M.; Zhang, W.; Corey, E.; et al. A positive role of c-Myc in regulating androgen receptor and its splice variants in prostate cancer. Oncogene 2019, 38, 4977-4989. [CrossRef]

87. Hanahan, D.; Weinberg, R.A. The hallmarks of cancer. Cell 2000, 100, 57-70. [CrossRef]

88. Woods, N.T.; Yamaguchi, H.; Lee, F.Y.; Bhalla, K.N.; Wang, H.G. Anoikis, initiated by Mcl-1 degradation and Bim induction, is deregulated during oncogenesis. Cancer Res. 2007, 67, 10744-10752. [CrossRef]

89. Shimizu, S.; Eguchi, Y.; Kosaka, H.; Kamiike, W.; Matsuda, H.; Tsujimoto, Y. Prevention of hypoxia-induced cell death by Bcl-2 and Bcl-xL. Nature 1995, 374, 811-813. [CrossRef]

90. Campbell, K.J.; Tait, S.W.G. Targeting BCL-2 regulated apoptosis in cancer. Open Biol. 2018, 8, 180002. [CrossRef] [PubMed]

91. Fernald, K.; Kurokawa, M. Evading apoptosis in cancer. Trends Cell Biol. 2013, 23, 620-633. [CrossRef]

92. Inuzuka, H.; Shaik, S.; Onoyama, I.; Gao, D.; Tseng, A.; Maser, R.S.; Zhai, B.; Wan, L.; Gutierrez, A.; Lau, A.W.; et al. SCF(FBW7) regulates cellular apoptosis by targeting MCL1 for ubiquitylation and destruction. Nature 2011, 471, 104-109. [CrossRef] [PubMed]

93. Ding, Q.; He, X.; Hsu, J.M.; Xia, W.; Chen, C.T.; Li, L.Y.; Lee, D.F.; Liu, J.C.; Zhong, Q.; Wang, X.; et al. Degradation of Mcl-1 by beta-TrCP mediates glycogen synthase kinase 3-induced tumor suppression and chemosensitization. Mol. Cell Biol. 2007, 27, 4006-4017. [CrossRef] [PubMed]

94. Schwickart, M.; Huang, X.; Lill, J.R.; Liu, J.; Ferrando, R.; French, D.M.; Maecker, H.; O’Rourke, K.; Bazan, F.; Eastham-Anderson, J.; et al. Deubiquitinase USP9X stabilizes MCL1 and promotes tumour cell survival. Nature 2010, 463, 103-107. [CrossRef]

95. Roberts, A.W.; Seymour, J.F.; Brown, J.R.; Wierda, W.G.; Kipps, T.J.; Khaw, S.L.; Carney, D.A.; He, S.Z.; Huang, D.C.; Xiong, H.; et al. Substantial susceptibility of chronic lymphocytic leukemia to BCL2 inhibition: Results of a phase I study of navitoclax in patients with relapsed or refractory disease. J. Clin. Oncol. 2012, 30, 488-496. [CrossRef] [PubMed]

96. Punnoose, E.A.; Leverson, J.D.; Peale, F.; Boghaert, E.R.; Belmont, L.D.; Tan, N.; Young, A.; Mitten, M.; Ingalla, E.; Darbonne, W.C.; et al. Expression profile of BCL-2, BCL-XL, and MCL-1 predicts pharmacological response to the BCL-2 selective antagonist venetoclax in multiple myeloma models. Mol. Cancer Ther. 2016, 15, 1132-1144. [CrossRef]

97. Morales, A.A.; Kurtoglu, M.; Matulis, S.M.; Liu, J.; Siefker, D.; Gutman, D.M.; Kaufman, J.L.; Lee, K.P.; Lonial, S.; Boise, L.H. Distribution of Bim determines Mcl-1 dependence or codependence with Bcl-xL/Bcl-2 in Mcl-1-expressing myeloma cells. Blood 2011, 118, 1329-1339. [CrossRef]

98. Weeden, C.E.; Ah-Cann, C.; Holik, A.Z.; Pasquet, J.; Garnier, J.M.; Merino, D.; Lessene, G.; Asselin-Labat, M.L. Dual inhibition of BCL-XL and MCL-1 is required to induce tumour regression in lung squamous cell carcinomas sensitive to FGFR inhibition. Oncogene 2018, 37, 4475-4488. [CrossRef] 
99. Soderquist, R.S.; Crawford, L.; Liu, E.; Lu, M.; Agarwal, A.; Anderson, G.R.; Lin, K.H.; Winter, P.S.; Cakir, M.; Wood, K.C. Systematic mapping of BCL-2 gene dependencies in cancer reveals molecular determinants of BH3 mimetic sensitivity. Nat. Commun. 2018, 9, 3513. [CrossRef]

100. Ryan, J.; Letai, A. BH3 profiling in whole cells by fluorimeter or FACS. Methods 2013, 61, 156-164. [CrossRef]

101. Certo, M.; Del Gaizo Moore, V.; Nishino, M.; Wei, G.; Korsmeyer, S.; Armstrong, S.A.; Letai, A. Mitochondria primed by death signals determine cellular addiction to antiapoptotic BCL-2 family members. Cancer Cell 2006, 9, 351-365. [CrossRef]

102. Gong, J.N.; Khong, T.; Segal, D.; Yao, Y.; Riffkin, C.D.; Garnier, J.M.; Khaw, S.L.; Lessene, G.; Spencer, A.; Herold, M.J.; et al. Hierarchy for targeting prosurvival BCL2 family proteins in multiple myeloma: Pivotal role of MCL1. Blood 2016, 128, 1834-1844. [CrossRef]

103. Tsherniak, A.; Vazquez, F.; Montgomery, P.G.; Weir, B.A.; Kryukov, G.; Cowley, G.S.; Gill, S.; Harrington, W.F.; Pantel, S.; Krill-Burger, J.M.; et al. Defining a cancer dependency map. Cell 2017, 170, 564-576. [CrossRef] [PubMed]

104. Liu, G.; Kelly, W.K.; Wilding, G.; Leopold, L.; Brill, K.; Somer, B. An open-label, multicenter, phase I/II study of single-agent AT-101 in men with castrate-resistant prostate cancer. Clin. Cancer Res. 2009, 15, 3172-3176. [CrossRef] [PubMed]

105. Schimmer, A.D.; Raza, A.; Carter, T.H.; Claxton, D.; Erba, H.; DeAngelo, D.J.; Tallman, M.S.; Goard, C.; Borthakur, G. A multicenter phase I/II study of obatoclax mesylate administered as a 3- or 24-hour infusion in older patients with previously untreated acute myeloid leukemia. PLoS ONE 2014, 9, e108694. [CrossRef] [PubMed]

106. Besbes, S.; Mirshahi, M.; Pocard, M.; Billard, C. New dimension in therapeutic targeting of BCL-2 family proteins. Oncotarget 2015, 6, 12862-12871. [CrossRef]

107. Oltersdorf, T.; Elmore, S.W.; Shoemaker, A.R.; Armstrong, R.C.; Augeri, D.J.; Belli, B.A.; Bruncko, M.; Deckwerth, T.L.; Dinges, J.; Hajduk, P.J.; et al. An inhibitor of Bcl-2 family proteins induces regression of solid tumours. Nature 2005, 435, 677-681. [CrossRef]

108. Tse, C.; Shoemaker, A.R.; Adickes, J.; Anderson, M.G.; Chen, J.; Jin, S.; Johnson, E.F.; Marsh, K.C.; Mitten, M.J.; Nimmer, P.; et al. ABT-263: A potent and orally bioavailable Bcl-2 family inhibitor. Cancer Res. 2008, 68, 3421-3428. [CrossRef]

109. Wilson, W.H.; O'Connor, O.A.; Czuczman, M.S.; LaCasce, A.S.; Gerecitano, J.F.; Leonard, J.P.; Tulpule, A.; Dunleavy, K.; Xiong, H.; Chiu, Y.L.; et al. Navitoclax, a targeted high-affinity inhibitor of BCL-2, in lymphoid malignancies: A phase 1 dose-escalation study of safety, pharmacokinetics, pharmacodynamics, and antitumour activity. Lancet Oncol. 2010, 11, 1149-1159. [CrossRef]

110. Gandhi, L.; Camidge, D.R.; Ribeiro de Oliveira, M.; Bonomi, P.; Gandara, D.; Khaira, D.; Hann, C.L.; McKeegan, E.M.; Litvinovich, E.; Hemken, P.M.; et al. Phase I study of Navitoclax (ABT-263), a novel Bcl-2 family inhibitor, in patients with small-cell lung cancer and other solid tumors. J. Clin. Oncol. 2011, 29, 909-916. [CrossRef]

111. Souers, A.J.; Leverson, J.D.; Boghaert, E.R.; Ackler, S.L.; Catron, N.D.; Chen, J.; Dayton, B.D.; Ding, H.; Enschede, S.H.; Fairbrother, W.J.; et al. ABT-199, a potent and selective BCL-2 inhibitor, achieves antitumor activity while sparing platelets. Nat. Med. 2013, 19, 202-208. [CrossRef] [PubMed]

112. Wei, A.H.; Montesinos, P.; Ivanov, V.; DiNardo, C.D.; Novak, J.; Laribi, K.; Kim, I.; Stevens, D.A.; Fiedler, W.; Pagoni, M.; et al. Venetoclax plus LDAC for newly diagnosed AML ineligible for intensive chemotherapy: A phase 3 randomized placebo-controlled trial. Blood 2020, 135, 2137-2145. [CrossRef] [PubMed]

113. DiNardo, C.D.; Jonas, B.A.; Pullarkat, V.; Thirman, M.J.; Garcia, J.S.; Wei, A.H.; Konopleva, M.; Dohner, H.; Letai, A.; Fenaux, P.; et al. Azacitidine and venetoclax in previously untreated acute myeloid leukemia. N. Engl. J. Med. 2020, 383, 617-629. [CrossRef] [PubMed]

114. Roberts, A.W.; Davids, M.S.; Pagel, J.M.; Kahl, B.S.; Puvvada, S.D.; Gerecitano, J.F.; Kipps, T.J.; Anderson, M.A.; Brown, J.R.; Gressick, L.; et al. Targeting BCL2 with venetoclax in relapsed chronic lymphocytic leukemia. N. Engl. J. Med. 2016, 374, 311-322. [CrossRef]

115. Seymour, J.F.; Kipps, T.J.; Eichhorst, B.; Hillmen, P.; D’Rozario, J.; Assouline, S.; Owen, C.; Gerecitano, J.; Robak, T.; De la Serna, J.; et al. Venetoclax-rituximab in relapsed or refractory chronic lymphocytic leukemia. N. Engl. J. Med. 2018, 378, 1107-1120. [CrossRef] [PubMed]

116. Fischer, K.; Al-Sawaf, O.; Bahlo, J.; Fink, A.M.; Tandon, M.; Dixon, M.; Robrecht, S.; Warburton, S.; Humphrey, K.; Samoylova, O.; et al. Venetoclax and obinutuzumab in patients with CLL and coexisting conditions. N. Engl. J. Med. 2019, 380, 2225-2236. [CrossRef] [PubMed]

117. Roberts, A.W.; Ma, S.; Kipps, T.J.; Coutre, S.E.; Davids, M.S.; Eichhorst, B.; Hallek, M.; Byrd, J.C.; Humphrey, K.; Zhou, L.; et al. Efficacy of venetoclax in relapsed chronic lymphocytic leukemia is influenced by disease and response variables. Blood 2019, 134, 111-122. [CrossRef]

118. Davids, M.S.; Roberts, A.W.; Seymour, J.F.; Pagel, J.M.; Kahl, B.S.; Wierda, W.G.; Puvvada, S.; Kipps, T.J.; Anderson, M.A.; Salem, A.H.; et al. Phase I first-in-human study of venetoclax in patients with relapsed or refractory non-Hodgkin lymphoma. J. Clin. Oncol. 2017, 35, 826-833. [CrossRef]

119. Klanova, M.; Andera, L.; Brazina, J.; Svadlenka, J.; Benesova, S.; Soukup, J.; Prukova, D.; Vejmelkova, D.; Jaksa, R.; Helman, K.; et al. Targeting of BCL2 family proteins with ABT-199 and homoharringtonine reveals BCL2- and MCL1-dependent subgroups of diffuse large B-Cell lymphoma. Clin. Cancer Res. 2016, 22, 1138-1149. [CrossRef]

120. Pan, R.; Hogdal, L.J.; Benito, J.M.; Bucci, D.; Han, L.; Borthakur, G.; Cortes, J.; DeAngelo, D.J.; Debose, L.; Mu, H.; et al. Selective BCL-2 inhibition by ABT-199 causes on-target cell death in acute myeloid leukemia. Cancer Discov. 2014, 4, 362-375. [CrossRef] 
121. Rahmani, M.; Nkwocha, J.; Hawkins, E.; Pei, X.; Parker, R.E.; Kmieciak, M.; Leverson, J.D.; Sampath, D.; Ferreira-Gonzalez, A.; Grant, S. Cotargeting BCL-2 and PI3K induces BAX-dependent mitochondrial apoptosis in AML cells. Cancer Res. 2018, 78, 3075-3086. [CrossRef]

122. Hafezi, S.; Rahmani, M. Targeting BCL-2 in cancer: Advances, challenges, and perspectives. Cancers 2021, 13, 1292. [CrossRef] [PubMed]

123. Lasica, M.; Anderson, M.A. Review of venetoclax in CLL, AML and multiple myeloma. J. Pers. Med. 2021, 11, 463. [CrossRef]

124. Guieze, R.; Liu, V.M.; Rosebrock, D.; Jourdain, A.A.; Hernandez-Sanchez, M.; Martinez Zurita, A.; Sun, J.; Ten Hacken, E.; Baranowski, K.; Thompson, P.A.; et al. Mitochondrial reprogramming underlies resistance to BCL-2 inhibition in lymphoid malignancies. Cancer Cell 2019, 36, 369-384. [CrossRef]

125. Blombery, P.; Anderson, M.A.; Gong, J.N.; Thijssen, R.; Birkinshaw, R.W.; Thompson, E.R.; Teh, C.E.; Nguyen, T.; Xu, Z.; Flensburg, C.; et al. Acquisition of the recurrent Gly101Val mutation in BCL2 confers resistance to venetoclax in patients with progressive chronic lymphocytic leukemia. Cancer Discov. 2019, 9, 342-353. [CrossRef] [PubMed]

126. Nechiporuk, T.; Kurtz, S.E.; Nikolova, O.; Liu, T.; Jones, C.L.; D’Alessandro, A.; Culp-Hill, R.; d'Almeida, A.; Joshi, S.K.; Rosenberg, M.; et al. The TP53 apoptotic network is a primary mediator of resistance to BCL2 inhibition in AML cells. Cancer Discov. 2019, 9, 910-925. [CrossRef]

127. Lochmann, T.L.; Floros, K.V.; Naseri, M.; Powell, K.M.; Cook, W.; March, R.J.; Stein, G.T.; Greninger, P.; Maves, Y.K.; Saunders, L.R.; et al. Venetoclax is effective in small-cell lung cancers with high BCL-2 expression. Clin. Cancer Res. 2018, 24, 360-369. [CrossRef]

128. Liu, W.; Krump, N.A.; Herlyn, M.; You, J. Combining DNA damage induction with BCL-2 inhibition to enhance Merkel cell carcinoma cytotoxicity. Biology 2020, 9, 35. [CrossRef] [PubMed]

129. Whittle, J.R.; Vaillant, F.; Surgenor, E.; Policheni, A.N.; Giner, G.; Capaldo, B.D.; Chen, H.R.; Liu, H.K.; Dekkers, J.F.; Sachs, N.; et al. Dual targeting of CDK4/6 and BCL2 pathways augments tumor response in estrogen receptor-positive breast cancer. Clin. Cancer Res. 2020, 26, 4120-4134. [CrossRef] [PubMed]

130. Karpel-Massler, G.; Ishida, C.T.; Bianchetti, E.; Shu, C.; Perez-Lorenzo, R.; Horst, B.; Banu, M.; Roth, K.A.; Bruce, J.N.; Canoll, P.; et al. Inhibition of mitochondrial matrix chaperones and antiapoptotic Bcl-2 family proteins empower antitumor therapeutic responses. Cancer Res. 2017, 77, 3513-3526. [CrossRef]

131. Lok, S.W.; Whittle, J.R.; Vaillant, F.; Teh, C.E.; Lo, L.L.; Policheni, A.N.; Bergin, A.R.T.; Desai, J.; Ftouni, S.; Gandolfo, L.C.; et al. A phase $\mathrm{Ib}$ dose-escalation and expansion study of the BCL2 inhibitor venetoclax combined with tamoxifen in ER and BCL2-positive metastatic breast cancer. Cancer Discov. 2019, 9, 354-369. [CrossRef] [PubMed]

132. Lindeman, G.J.; Bowen, R.; Jerzak, K.J.; Song, X.; Decker, T.; Boyle, F.M.; McCune, S.L.; Armstrong, A.; Shannon, C.M.; Bertelli, G.; et al. Results from VERONICA: A randomized, phase II study of second-/third-line venetoclax (VEN) + fulvestrant (F) versus $\mathrm{F}$ alone in estrogen receptor (ER)-positive, HER2-negative, locally advanced, or metastatic breast cancer (LA/MBC). J. Clin. Oncol. 2021, 39, 1004. [CrossRef]

133. Kehr, S.; Vogler, M. It's time to die: BH3 mimetics in solid tumors. Biochimica Biophysica Acta Mol. Cell. Res. 2021, $1868,118987$. [CrossRef]

134. Ow, T.J.; Fulcher, C.D.; Thomas, C.; Broin, P.O.; Lopez, A.; Reyna, D.E.; Smith, R.V.; Sarta, C.; Prystowsky, M.B.; Schlecht, N.F.; et al. Optimal targeting of BCL-family proteins in head and neck squamous cell carcinoma requires inhibition of both BCL-xL and MCL-1. Oncotarget 2019, 10, 494-510. [CrossRef]

135. Levesley, J.; Steele, L.; Bruning-Richardson, A.; Davison, A.; Zhou, J.; Ding, C.; Lawler, S.; Short, S.C. Selective BCL-XL inhibition promotes apoptosis in combination with MLN8237 in medulloblastoma and pediatric glioblastoma cells. Neuro. Oncol. 2018, 20, 203-214. [CrossRef]

136. Lee, E.F.; Harris, T.J.; Tran, S.; Evangelista, M.; Arulananda, S.; John, T.; Ramnac, C.; Hobbs, C.; Zhu, H.; Gunasingh, G.; et al. BCL-XL and MCL-1 are the key BCL-2 family proteins in melanoma cell survival. Cell Death Dis. 2019, 10, 342. [CrossRef]

137. Beroukhim, R.; Mermel, C.H.; Porter, D.; Wei, G.; Raychaudhuri, S.; Donovan, J.; Barretina, J.; Boehm, J.S.; Dobson, J.; Urashima, M.; et al. The landscape of somatic copy-number alteration across human cancers. Nature 2010, 463, 899-905. [CrossRef]

138. Amundson, S.A.; Myers, T.G.; Scudiero, D.; Kitada, S.; Reed, J.C.; Fornace, A.J., Jr. An informatics approach identifying markers of chemosensitivity in human cancer cell lines. Cancer Res. 2000, 60, 6101-6110. [PubMed]

139. Trisciuoglio, D.; Tupone, M.G.; Desideri, M.; Di Martile, M.; Gabellini, C.; Buglioni, S.; Pallocca, M.; Alessandrini, G.; D’Aguanno, S.; Del Bufalo, D. BCL-XL overexpression promotes tumor progression-associated properties. Cell Death Dis. 2017, 8, 3216. [CrossRef] [PubMed]

140. Baranski, Z.; de Jong, Y.; Ilkova, T.; Peterse, E.F.; Cleton-Jansen, A.M.; van de Water, B.; Hogendoorn, P.C.; Bovee, J.V.; Danen, E.H. Pharmacological inhibition of Bcl-xL sensitizes osteosarcoma to doxorubicin. Oncotarget 2015, 6, 36113-36125. [CrossRef]

141. Abed, M.N.; Abdullah, M.I.; Richardson, A. Antagonism of Bcl-XL is necessary for synergy between carboplatin and BH3 mimetics in ovarian cancer cells. J. Ovarian Res. 2016, 9, 25. [CrossRef]

142. Lucantoni, F.; Lindner, A.U.; O’Donovan, N.; Dussmann, H.; Prehn, J.H.M. Systems modeling accurately predicts responses to genotoxic agents and their synergism with BCL-2 inhibitors in triple negative breast cancer cells. Cell Death Dis. $2018,9,42$. [CrossRef] 
143. Tao, Z.F.; Hasvold, L.; Wang, L.; Wang, X.; Petros, A.M.; Park, C.H.; Boghaert, E.R.; Catron, N.D.; Chen, J.; Colman, P.M.; et al. Discovery of a potent and selective BCL-XL inhibitor with in vivo activity. ACS Med. Chem. Lett. 2014, 5, 1088-1093. [CrossRef] [PubMed]

144. Wang, L.; Doherty, G.A.; Judd, A.S.; Tao, Z.F.; Hansen, T.M.; Frey, R.R.; Song, X.; Bruncko, M.; Kunzer, A.R.; Wang, X.; et al. Discovery of A-1331852, a first-in-class, potent, and orally-bioavailable BCL-XL inhibitor. ACS Med. Chem. Lett. 2020, 11, 1829-1836. [CrossRef] [PubMed]

145. Leverson, J.D.; Phillips, D.C.; Mitten, M.J.; Boghaert, E.R.; Diaz, D.; Tahir, S.K.; Belmont, L.D.; Nimmer, P.; Xiao, Y.; Ma, X.M.; et al. Exploiting selective BCL-2 family inhibitors to dissect cell survival dependencies and define improved strategies for cancer therapy. Sci. Transl. Med. 2015, 7, 279ra40. [CrossRef]

146. Lessene, G.; Czabotar, P.E.; Sleebs, B.E.; Zobel, K.; Lowes, K.N.; Adams, J.M.; Baell, J.B.; Colman, P.M.; Deshayes, K.; Fairbrother, W.J.; et al. Structure-guided design of a selective BCL-X(L) inhibitor. Nat. Chem. Biol. 2013, 9, 390-397. [CrossRef] [PubMed]

147. Tolcher, A.W.; Carneiro, B.A.; Dowlati, A.; Razak, A.R.A.; Chae, Y.K.; Villella, J.A.; Coppola, S.; Englert, S.; Phillips, A.C.; Souers, A.J.; et al. A first-in-human study of mirzotamab clezutoclax as monotherapy and in combination with taxane therapy in relapsed/refractory solid tumors: Dose escalation results. J. Clin. Oncol. 2021, 39, 3015. [CrossRef]

148. He, Y.; Koch, R.; Budamagunta, V.; Zhang, P.; Zhang, X.; Khan, S.; Thummuri, D.; Ortiz, Y.T.; Zhang, X.; Lv, D.; et al. DT2216-a Bcl-xL-specific degrader is highly active against Bcl-xL-dependent T cell lymphomas. J. Hematol. Oncol. 2020, 13, 95. [CrossRef]

149. Khan, S.; Zhang, X.; Lv, D.; Zhang, Q.; He, Y.; Zhang, P.; Liu, X.; Thummuri, D.; Yuan, Y.; Wiegand, J.S.; et al. A selective BCL-XL PROTAC degrader achieves safe and potent antitumor activity. Nat. Med. 2019, 25, 1938-1947. [CrossRef]

150. Kolb, R.; De, U.; Khan, S.; Luo, Y.; Kim, M.C.; Yu, H.; Wu, C.; Mo, J.; Zhang, X.; Zhang, P.; et al. Proteolysis-targeting chimera against BCL-XL destroys tumor-infiltrating regulatory T cells. Nat. Commun. 2021, 12, 1281. [CrossRef]

151. Patterson, C.M.; Balachander, S.B.; Grant, I.; Pop-Damkov, P.; Kelly, B.; McCoull, W.; Parker, J.; Giannis, M.; Hill, K.J.; Gibbons, F.D.; et al. Design and optimisation of dendrimer-conjugated Bcl-2/xL inhibitor, AZD0466, with improved therapeutic index for cancer therapy. Commun. Biol. 2021, 4, 112. [CrossRef]

152. Arulananda, S.; O’Brien, M.; Evangelista, M.; Jenkins, L.J.; Poh, A.R.; Walkiewicz, M.; Leong, T.; Mariadason, J.M.; Cebon, J.; Balachander, S.B.; et al. A novel BH3-mimetic, AZD0466, targeting BCL-XL and BCL-2 is effective in pre-clinical models of malignant pleural mesothelioma. Cell Death Discov. 2021, 7, 122. [CrossRef] [PubMed]

153. Lakhani, N.J.; Rasco, D.W.; Zeng, Q.; Tang, Y.; Liang, Z.; Wang, H.; Lu, M.; Chen, J.; Fu, L.; Wang, C.; et al. First-in-human study of palcitoclax (APG-1252), a novel dual Bcl-2/Bcl-xL inhibitor, demonstrated advantages in platelet safety while maintaining anticancer effect in U.S. patients with metastatic solid tumors. J. Clin. Oncol. 2020, 38, 3509. [CrossRef]

154. Hamilton, C.; Fox, J.P.; Longley, D.B.; Higgins, C.A. Therapeutics targeting the core apoptotic machinery. Cancers 2021, 13, 2618. [CrossRef] [PubMed]

155. Zhang, B.; Gojo, I.; Fenton, R.G. Myeloid cell factor-1 is a critical survival factor for multiple myeloma. Blood 2002, 99, 1885-1893. [CrossRef]

156. Perciavalle, R.M.; Opferman, J.T. Delving deeper: MCL-1's contributions to normal and cancer biology. Trends Cell Biol. 2013, 23, 22-29. [CrossRef] [PubMed]

157. Grabow, S.; Delbridge, A.R.; Valente, L.J.; Strasser, A. MCL-1 but not BCL-XL is critical for the development and sustained expansion of thymic lymphoma in p53-deficient mice. Blood 2014, 124, 3939-3946. [CrossRef] [PubMed]

158. Glaser, S.P.; Lee, E.F.; Trounson, E.; Bouillet, P.; Wei, A.; Fairlie, W.D.; Izon, D.J.; Zuber, J.; Rappaport, A.R.; Herold, M.J.; et al. Anti-apoptotic Mcl-1 is essential for the development and sustained growth of acute myeloid leukemia. Genes Dev. 2012, 26, 120-125. [CrossRef]

159. Ashkenazi, A.; Fairbrother, W.J.; Leverson, J.D.; Souers, A.J. From basic apoptosis discoveries to advanced selective BCL-2 family inhibitors. Nat. Rev. Drug Discov. 2017, 16, 273-284. [CrossRef] [PubMed]

160. Bolomsky, A.; Vogler, M.; Kose, M.C.; Heckman, C.A.; Ehx, G.; Ludwig, H.; Caers, J. MCL-1 inhibitors, fast-lane development of a new class of anti-cancer agents. J. Hematol. Oncol. 2020, 13, 173. [CrossRef]

161. Williams, M.M.; Elion, D.L.; Rahman, B.; Hicks, D.J.; Sanchez, V.; Cook, R.S. Therapeutic inhibition of Mcl-1 blocks cell survival in estrogen receptor-positive breast cancers. Oncotarget 2019, 10, 5389-5402. [CrossRef]

162. Bhagwat, N.; Grego, A.; Gowen-MacDonald, W.; Wang, M.; Cowart, M.; Wu, X.; Zhuo, J.; Combs, A.; Ruggeri, B.; Scherle, P.; et al. Abstract 983: Preclinical characterization of PRT1419, a potent, selective and orally available inhibitor of MCL1. Cancer Res. 2021, 81, 983. [CrossRef]

163. Kotschy, A.; Szlavik, Z.; Murray, J.; Davidson, J.; Maragno, A.L.; Le Toumelin-Braizat, G.; Chanrion, M.; Kelly, G.L.; Gong, J.N.; Moujalled, D.M.; et al. The MCL1 inhibitor S63845 is tolerable and effective in diverse cancer models. Nature 2016, 538, 477-482. [CrossRef]

164. Tron, A.E.; Belmonte, M.A.; Adam, A.; Aquila, B.M.; Boise, L.H.; Chiarparin, E.; Cidado, J.; Embrey, K.J.; Gangl, E.; Gibbons, F.D.; et al. Discovery of Mcl-1-specific inhibitor AZD5991 and preclinical activity in multiple myeloma and acute myeloid leukemia. Nat. Commun. 2018, 9, 5341. [CrossRef]

165. Caenepeel, S.; Karen, R.; Belmontes, B.; Verlinsky, A.; Tan, H.; Yang, Y.; Chen, X.; Li, K.; Allen, J.; Wahlstrom, J.; et al. Abstract 6218: Discovery and preclinical evaluation of AMG 397, a potent, selective and orally bioavailable MCL1 inhibitor. Cancer Res. 2020, 80, 6218. [CrossRef] 
166. Caenepeel, S.; Brown, S.P.; Belmontes, B.; Moody, G.; Keegan, K.S.; Chui, D.; Whittington, D.A.; Huang, X.; Poppe, L.; Cheng, A.C.; et al. AMG 176, a selective MCL1 inhibitor, is effective in hematologic cancer models alone and in combination with established therapies. Cancer Discov. 2018, 8, 1582-1597. [CrossRef] [PubMed]

167. Slomp, A.; Moesbergen, L.M.; Gong, J.N.; Cuenca, M.; von dem Borne, P.A.; Sonneveld, P.; Huang, D.C.S.; Minnema, M.C.; Peperzak, V. Multiple myeloma with 1q21 amplification is highly sensitive to MCL-1 targeting. Blood Adv. 2019, 3, $4202-4214$. [CrossRef]

168. Yasuda, Y.; Ozasa, H.; Kim, Y.H.; Yamazoe, M.; Ajimizu, H.; Yamamoto Funazo, T.; Nomizo, T.; Tsuji, T.; Yoshida, H.; Sakamori, Y.; et al. MCL1 inhibition is effective against a subset of small-cell lung cancer with high MCL1 and low BCL-XL expression. Cell Death Dis. 2020, 11, 177. [CrossRef] [PubMed]

169. Munkhbaatar, E.; Dietzen, M.; Agrawal, D.; Anton, M.; Jesinghaus, M.; Boxberg, M.; Pfarr, N.; Bidola, P.; Uhrig, S.; Hockendorf, U.; et al. MCL-1 gains occur with high frequency in lung adenocarcinoma and can be targeted therapeutically. Nat. Commun. 2020, 11, 4527. [CrossRef]

170. Sale, M.J.; Minihane, E.; Monks, N.R.; Gilley, R.; Richards, F.M.; Schifferli, K.P.; Andersen, C.L.; Davies, E.J.; Vicente, M.A.; Ozono, E.; et al. Targeting melanoma's MCL1 bias unleashes the apoptotic potential of BRAF and ERK1/2 pathway inhibitors. Nat. Commun. 2019, 10, 5167. [CrossRef] [PubMed]

171. Vallet, S.; Fan, F.; Malvestiti, S.; Pecherstorfer, M.; Sattler, M.; Schneeweiss, A.; Schulze-Bergkamen, H.; Opferman, J.T.; Cardone, M.H.; Jager, D.; et al. Rationally derived drug combinations with the novel Mcl-1 inhibitor EU-5346 in breast cancer. Breast Cancer Res. Treat. 2019, 173, 585-596. [CrossRef]

172. Merino, D.; Whittle, J.R.; Vaillant, F.; Serrano, A.; Gong, J.N.; Giner, G.; Maragno, A.L.; Chanrion, M.; Schneider, E.; Pal, B.; et al. Synergistic action of the MCL-1 inhibitor S63845 with current therapies in preclinical models of triple-negative and HER2-amplified breast cancer. Sci. Transl. Med. 2017, 9. [CrossRef] [PubMed]

173. Spencer, A.; Rosenberg, A.S.; Jakubowiak, A.; Raje, N.; Chatterjee, M.; Trudel, S.; Bahlis, N.J.; Siegel, D.S.; Wilop, S.; Harrison, S.J.; et al. A phase 1, first-in-human study of AMG 176, a selective MCL-1 inhibitor, in patients with relapsed or refractory multiple myeloma. Clin. Lymphoma Myeloma Leuk. 2019, 19, e53-e54. [CrossRef]

174. Wang, X.; Bathina, M.; Lynch, J.; Koss, B.; Calabrese, C.; Frase, S.; Schuetz, J.D.; Rehg, J.E.; Opferman, J.T. Deletion of MCL-1 causes lethal cardiac failure and mitochondrial dysfunction. Genes Dev. 2013, 27, 1351-1364. [CrossRef] [PubMed]

175. Thomas, R.L.; Roberts, D.J.; Kubli, D.A.; Lee, Y.; Quinsay, M.N.; Owens, J.B.; Fischer, K.M.; Sussman, M.A.; Miyamoto, S.; Gustafsson, A.B. Loss of MCL-1 leads to impaired autophagy and rapid development of heart failure. Genes Dev. 2013, 27, 1365-1377. [CrossRef] [PubMed]

176. Matsushima, H.; Hosaka, Y.; Suzuki, M.; Mizutani, T.; Ishizuka, H.; Kawabe, K. bl-2 [corrected] expression on prostate cancer and its relationship to cell cycle and prognosis. Int. J. Urol. 1996, 3, 113-117. [CrossRef]

177. Krajewska, M.; Krajewski, S.; Epstein, J.I.; Shabaik, A.; Sauvageot, J.; Song, K.; Kitada, S.; Reed, J.C. Immunohistochemical analysis of bcl-2, bax, bcl-X, and mcl-1 expression in prostate cancers. Am. J. Pathol. 1996, 148, 1567-1576.

178. Yoshino, T.; Shiina, H.; Urakami, S.; Kikuno, N.; Yoneda, T.; Shigeno, K.; Igawa, M. Bcl-2 expression as a predictive marker of hormone-refractory prostate cancer treated with taxane-based chemotherapy. Clin. Cancer Res. 2006, 12, 6116-6124. [CrossRef]

179. Colombel, M.; Symmans, F.; Gil, S.; O’Toole, K.M.; Chopin, D.; Benson, M.; Olsson, C.A.; Korsmeyer, S.; Buttyan, R. Detection of the apoptosis-suppressing oncoprotein bc1-2 in hormone-refractory human prostate cancers. Am. J. Pathol. 1993, 143, 390-400. [PubMed]

180. Anvari, K.; Seilanian Toussi, M.; Kalantari, M.; Naseri, S.; Karimi Shahri, M.; Ahmadnia, H.; Katebi, M.; Sedighi Pashaki, A.; Dayani, M.; Broumand, M. Expression of Bcl-2 and Bax in advanced or metastatic prostate carcinoma. Urol. J. 2012, 9, 381-388.

181. Cho, I.C.; Chung, H.S.; Cho, K.S.; Kim, J.E.; Joung, J.Y.; Seo, H.K.; Chung, J.; Park, W.S.; Hong, E.K.; Lee, K.H. Bcl-2 as a predictive factor for biochemical recurrence after radical prostatectomy: An interim analysis. Cancer Res. Treat. 2010, 42, 157-162. [CrossRef]

182. Kaur, P.; Kallakury, B.S.; Sheehan, C.E.; Fisher, H.A.; Kaufman, R.P., Jr.; Ross, J.S. Survivin and Bcl-2 expression in prostatic adenocarcinomas. Arch. Pathol. Lab. Med. 2004, 128, 39-43. [CrossRef] [PubMed]

183. Borre, M.; Stausbol-Gron, B.; Nerstrom, B.; Overgaard, J. Immunohistochemical BCL-2 and KI-67 expression predict survival in prostate cancer patients followed expectantly. Prostate Cancer Prostatic Dis. 1998, 1, 268-275. [CrossRef] [PubMed]

184. Pfeil, K.; Eder, I.E.; Bektic, J.; Huebl, H.; Pycha, A.; Schaefer, G.; Rogatsch, H.; Bartsch, G.; Klocker, H. The anti-apoptotic protein Mcl-1 is overexpressed in prostate cancer. Cancer Res. 2004, 64, 1193.

185. Liang, Y.; Jeganathan, S.; Marastoni, S.; Sharp, A.; Figueiredo, I.; Marcellus, R.; Mawson, A.; Shalev, Z.; Pesic, A.; Sweet, J.; et al. Emergence of Enzalutamide resistance in prostate cancer is associated with BCL-2 and IKKB dependencies. Clin. Cancer Res. 2021, 27, 2340-2351. [CrossRef] [PubMed]

186. Akfirat, C.; Zhang, X.; Ventura, A.; Berel, D.; Colangelo, M.E.; Miranti, C.K.; Krajewska, M.; Reed, J.C.; Higano, C.S.; True, L.D.; et al. Tumour cell survival mechanisms in lethal metastatic prostate cancer differ between bone and soft tissue metastases. $J$. Pathol. 2013, 230, 291-297. [CrossRef]

187. Ali, A.; Kulik, G. Signaling pathways that control apoptosis in prostate cancer. Cancers 2021, 13, 937. [CrossRef]

188. Santer, F.R.; Erb, H.H.; Oh, S.J.; Handle, F.; Feiersinger, G.E.; Luef, B.; Bu, H.; Schafer, G.; Ploner, C.; Egger, M.; et al. Mechanistic rationale for MCL1 inhibition during androgen deprivation therapy. Oncotarget 2015, 6, 6105-6122. [CrossRef] 
189. McDonnell, T.J.; Troncoso, P.; Brisbay, S.M.; Logothetis, C.; Chung, L.W.; Hsieh, J.T.; Tu, S.M.; Campbell, M.L. Expression of the protooncogene bcl-2 in the prostate and its association with emergence of androgen-independent prostate cancer. Cancer Res. 1992, 52, 6940-6944.

190. Apakama, I.; Robinson, M.C.; Walter, N.M.; Charlton, R.G.; Royds, J.A.; Fuller, C.E.; Neal, D.E.; Hamdy, F.C. bcl-2 overexpression combined with p53 protein accumulation correlates with hormone-refractory prostate cancer. Br. J. Cancer 1996, 74, 1258-1262. [CrossRef]

191. Li, Q.; Deng, Q.; Chao, H.P.; Liu, X.; Lu, Y.; Lin, K.; Liu, B.; Tang, G.W.; Zhang, D.; Tracz, A.; et al. Linking prostate cancer cell AR heterogeneity to distinct castration and enzalutamide responses. Nat. Commun. 2018, 9, 3600. [CrossRef]

192. Kajiwara, T.; Takeuchi, T.; Ueki, T.; Moriyama, N.; Ueki, K.; Kakizoe, T.; Kawabe, K. Effect of Bcl-2 overexpression in human prostate cancer cells in vitro and in vivo. Int. J. Urol. 1999, 6, 520-525. [CrossRef]

193. Huang, H.; Zegarra-Moro, O.L.; Benson, D.; Tindall, D.J. Androgens repress Bcl-2 expression via activation of the retinoblastoma (RB) protein in prostate cancer cells. Oncogene 2004, 23, 2161-2176. [CrossRef]

194. Clegg, N.J.; Wongvipat, J.; Joseph, J.D.; Tran, C.; Ouk, S.; Dilhas, A.; Chen, Y.; Grillot, K.; Bischoff, E.D.; Cai, L.; et al. ARN-509: A novel antiandrogen for prostate cancer treatment. Cancer Res. 2012, 72, 1494-1503. [CrossRef]

195. Guerrero, J.; Alfaro, I.E.; Gomez, F.; Protter, A.A.; Bernales, S. Enzalutamide, an androgen receptor signaling inhibitor, induces tumor regression in a mouse model of castration-resistant prostate cancer. Prostate 2013, 73, 1291-1305. [CrossRef] [PubMed]

196. Pilling, A.B.; Hwang, C. Targeting prosurvival BCL2 signaling through Akt blockade sensitizes castration-resistant prostate cancer cells to enzalutamide. Prostate 2019, 79, 1347-1359. [CrossRef] [PubMed]

197. Corella, A.N.; Cabiliza Ordonio, M.V.A.; Coleman, I.; Lucas, J.M.; Kaipainen, A.; Nguyen, H.M.; Sondheim, D.; Brown, L.G.; True, L.D.; Lee, J.K.; et al. Identification of therapeutic vulnerabilities in small-cell neuroendocrine prostate cancer. Clin. Cancer Res. 2020, 26, 1667-1677. [CrossRef]

198. Bluemn, E.G.; Coleman, I.M.; Lucas, J.M.; Coleman, R.T.; Hernandez-Lopez, S.; Tharakan, R.; Bianchi-Frias, D.; Dumpit, R.F.; Kaipainen, A.; Corella, A.N.; et al. Androgen receptor pathway-independent prostate cancer is sustained through FGF signaling. Cancer Cell 2017, 32, 474-489. [CrossRef]

199. Mu, P.; Zhang, Z.; Benelli, M.; Karthaus, W.R.; Hoover, E.; Chen, C.C.; Wongvipat, J.; Ku, S.Y.; Gao, D.; Cao, Z.; et al. SOX2 promotes lineage plasticity and antiandrogen resistance in TP53- and RB1-deficient prostate cancer. Science 2017, 355, 84-88. [CrossRef] [PubMed]

200. Vlachostergios, P.J.; Puca, L.; Beltran, H. Emerging variants of castration-resistant prostate cancer. Curr. Oncol. Rep. 2017, 19, 32. [CrossRef]

201. Beltran, H.; Rickman, D.S.; Park, K.; Chae, S.S.; Sboner, A.; MacDonald, T.Y.; Wang, Y.; Sheikh, K.L.; Terry, S.; Tagawa, S.T.; et al. Molecular characterization of neuroendocrine prostate cancer and identification of new drug targets. Cancer Discov. 2011, 1, 487-495. [CrossRef]

202. James, N.D.; Sydes, M.R.; Clarke, N.W.; Mason, M.D.; Dearnaley, D.P.; Spears, M.R.; Ritchie, A.W.; Parker, C.C.; Russell, J.M.; Attard, G.; et al. Addition of docetaxel, zoledronic acid, or both to first-line long-term hormone therapy in prostate cancer (STAMPEDE): Survival results from an adaptive, multiarm, multistage, platform randomised controlled trial. Lancet 2016, 387, 1163-1177. [CrossRef]

203. Liu, Q.; Harvey, C.T.; Geng, H.; Xue, C.; Chen, V.; Beer, T.M.; Qian, D.Z. Malate dehydrogenase 2 confers docetaxel resistance via regulations of JNK signaling and oxidative metabolism. Prostate 2013, 73, 1028-1037. [CrossRef]

204. Karanika, S.; Karantanos, T.; Kurosaka, S.; Wang, J.; Hirayama, T.; Yang, G.; Park, S.; Golstov, A.A.; Tanimoto, R.; Li, L.; et al. GLIPR1-DeltaTM synergizes with docetaxel in cell death and suppresses resistance to docetaxel in prostate cancer cells. Mol. Cancer 2015, 14, 122. [CrossRef]

205. Wang, L.G.; Liu, X.M.; Kreis, W.; Budman, D.R. The effect of antimicrotubule agents on signal transduction pathways of apoptosis: A review. Cancer Chemother. Pharmacol. 1999, 44, 355-361. [CrossRef] [PubMed]

206. Haschka, M.D.; Karbon, G.; Soratroi, C.; O’Neill, K.L.; Luo, X.; Villunger, A. MARCH5-dependent degradation of MCL1/NOXA complexes defines susceptibility to antimitotic drug treatment. Cell Death Differ. 2020, 27, 2297-2312. [CrossRef] [PubMed]

207. Ruiz de Porras, V.; Wang, X.C.; Palomero, L.; Marin-Aguilera, M.; Sole-Blanch, C.; Indacochea, A.; Jimenez, N.; Bystrup, S.; Bakht, M.; Conteduca, V.; et al. Taxane-induced attenuation of the CXCR2/BCL-2 axis sensitizes prostate cancer to platinum-based treatment. Eur. Urol. 2021, 79, 722-733. [CrossRef] [PubMed]

208. Haldar, S.; Chintapalli, J.; Croce, C.M. Taxol induces bcl-2 phosphorylation and death of prostate cancer cells. Cancer Res. 1996, 56, 1253-1255.

209. Mackey, T.J.; Borkowski, A.; Amin, P.; Jacobs, S.C.; Kyprianou, N. bcl-2/bax ratio as a predictive marker for therapeutic response to radiotherapy in patients with prostate cancer. Urology 1998, 52, 1085-1090. [CrossRef]

210. Khor, L.Y.; Moughan, J.; Al-Saleem, T.; Hammond, E.H.; Venkatesan, V.; Rosenthal, S.A.; Ritter, M.A.; Sandler, H.M.; Hanks, G.E.; Shipley, W.U.; et al. Bcl-2 and Bax expression predict prostate cancer outcome in men treated with androgen deprivation and radiotherapy on radiation therapy oncology group protocol 92-02. Clin. Cancer Res. 2007, 13, 3585-3590. [CrossRef]

211. Arai, S.; Jonas, O.; Whitman, M.A.; Corey, E.; Balk, S.P.; Chen, S. Tyrosine kinase inhibitors increase MCL1 degradation and in combination with BCLXL/BCL2 inhibitors drive prostate cancer apoptosis. Clin. Cancer Res. 2018, 24, 5458-5470. [CrossRef] 
212. Leverson, J.D.; Zhang, H.; Chen, J.; Tahir, S.K.; Phillips, D.C.; Xue, J.; Nimmer, P.; Jin, S.; Smith, M.; Xiao, Y.; et al. Potent and selective small-molecule MCL-1 inhibitors demonstrate on-target cancer cell killing activity as single agents and in combination with ABT-263 (navitoclax). Cell Death Dis. 2015, 6, e1590. [CrossRef] [PubMed]

213. Mukherjee, N.; Skees, J.; Todd, K.J.; West, D.A.; Lambert, K.A.; Robinson, W.A.; Amato, C.M.; Couts, K.L.; Van Gulick, R.; MacBeth, M.; et al. MCL1 inhibitors S63845/MIK665 plus Navitoclax synergistically kill difficult-to-treat melanoma cells. Cell Death Dis. 2020, 11, 443. [CrossRef]

214. Jackson, R.S., 2nd; Placzek, W.; Fernandez, A.; Ziaee, S.; Chu, C.Y.; Wei, J.; Stebbins, J.; Kitada, S.; Fritz, G.; Reed, J.C.; et al. Sabutoclax, a Mcl-1 antagonist, inhibits tumorigenesis in transgenic mouse and human xenograft models of prostate cancer. Neoplasia 2012, 14, 656-665. [CrossRef] [PubMed]

215. Wei, J.; Stebbins, J.L.; Kitada, S.; Dash, R.; Zhai, D.; Placzek, W.J.; Wu, B.; Rega, M.F.; Zhang, Z.; Barile, E.; et al. An optically pure apogossypolone derivative as potent pan-active inhibitor of anti-apoptotic bcl-2 family proteins. Front. Oncol. 2011, 1, 28. [CrossRef]

216. Sonpavde, G.; Matveev, V.; Burke, J.M.; Caton, J.R.; Fleming, M.T.; Hutson, T.E.; Galsky, M.D.; Berry, W.R.; Karlov, P.; Holmlund, J.T.; et al. Randomized phase II trial of docetaxel plus prednisone in combination with placebo or AT-101, an oral small molecule Bcl-2 family antagonist, as first-line therapy for metastatic castration-resistant prostate cancer. Ann. Oncol. 2012, 23, 1803-1808. [CrossRef] [PubMed]

217. Stein, M.N.; Hussain, M.; Stadler, W.M.; Liu, G.; Tereshchenko, I.V.; Goodin, S.; Jeyamohan, C.; Kaufman, H.L.; Mehnert, J.; DiPaola, R.S. A phase II study of AT-101 to overcome Bcl-2-Mediated resistance to androgen deprivation therapy in patients with newly diagnosed castration-sensitive metastatic prostate cancer. Clin. Genitourin. Cancer 2016, 14, 22-27. [CrossRef]

218. Xu, H.; Sun, Y.; Huang, C.P.; You, B.; Ye, D.; Chang, C. Preclinical study using ABT263 to increase enzalutamide sensitivity to suppress prostate cancer progression via targeting BCL2/ROS/USP26 axis through altering ARv7 protein degradation. Cancers 2020, 12, 831. [CrossRef] [PubMed]

219. Nadal, R.; Schweizer, M.; Kryvenko, O.N.; Epstein, J.I.; Eisenberger, M.A. Small cell carcinoma of the prostate. Nat. Rev. Urol. 2014, 11, 213-219. [CrossRef]

220. Tamaki, H.; Harashima, N.; Hiraki, M.; Arichi, N.; Nishimura, N.; Shiina, H.; Naora, K.; Harada, M. Bcl-2 family inhibition sensitizes human prostate cancer cells to docetaxel and promotes unexpected apoptosis under caspase-9 inhibition. Oncotarget 2014, 5, 11399-11412. [CrossRef]

221. Parrondo, R.; de Las Pozas, A.; Reiner, T.; Perez-Stable, C. ABT-737, a small molecule Bcl-2/Bcl-xL antagonist, increases antimitotic-mediated apoptosis in human prostate cancer cells. Peer] 2013, 1, e144. [CrossRef]

222. Wang, C.; Huang, S.B.; Yang, M.C.; Lin, Y.T.; Chu, I.H.; Shen, Y.N.; Chiu, Y.H.; Hung, S.H.; Kang, L.; Hong, Y.R.; et al. Combining paclitaxel with ABT-263 has a synergistic effect on paclitaxel resistant prostate cancer cells. PLoS ONE 2015, 10, e0120913. [CrossRef]

223. Puhr, M.; Hoefer, J.; Neuwirt, H.; Eder, I.E.; Kern, J.; Schafer, G.; Geley, S.; Heidegger, I.; Klocker, H.; Culig, Z. PIAS1 is a crucial factor for prostate cancer cell survival and a valid target in docetaxel resistant cells. Oncotarget 2014, 5, 12043-12056. [CrossRef] [PubMed]

224. Cui, J.; Placzek, W.J. PTBP1 modulation of MCL1 expression regulates cellular apoptosis induced by antitubulin chemotherapeutics. Cell Death Differ. 2016, 23, 1681-1690. [CrossRef] [PubMed]

225. Robinson, D.; Van Allen, E.M.; Wu, Y.M.; Schultz, N.; Lonigro, R.J.; Mosquera, J.M.; Montgomery, B.; Taplin, M.E.; Pritchard, C.C.; Attard, G.; et al. Integrative clinical genomics of advanced prostate cancer. Cell 2015, 161, 1215-1228. [CrossRef]

226. Abida, W.; Cyrta, J.; Heller, G.; Prandi, D.; Armenia, J.; Coleman, I.; Cieslik, M.; Benelli, M.; Robinson, D.; Van Allen, E.M.; et al Genomic correlates of clinical outcome in advanced prostate cancer. Proc. Natl. Acad. Sci. USA 2019, 116, 11428-11436. [CrossRef]

227. Cancer Genome Atlas Research Network. The molecular taxonomy of primary prostate cancer. Cell 2015, 163, 1011-1025. [CrossRef] [PubMed]

228. Sastry, K.S.R.; Smith, A.J.; Karpova, Y.; Datta, S.R.; Kulik, G. Diverse antiapoptotic signaling pathways activated by vasoactive intestinal polypeptide, epidermal growth factor, and phosphatidylinositol 3-kinase in prostate cancer cells converge on BAD. J. Biol. Chem. 2006, 281, 20891-20901. [CrossRef]

229. Datta, S.R.; Dudek, H.; Tao, X.; Masters, S.; Fu, H.; Gotoh, Y.; Greenberg, M.E. Akt phosphorylation of BAD couples survival signals to the cell-intrinsic death machinery. Cell 1997, 91, 231-241. [CrossRef]

230. Ren, W.; Joshi, R.; Mathew, P. Synthetic lethality in PTEN-mutant prostate cancer is induced by combinatorial PI3K/Akt and BCL-XL inhibition. Mol. Cancer Res. 2016, 14, 1176-1181. [CrossRef]

231. Sastry, K.S.; Karpova, Y.; Kulik, G. Epidermal growth factor protects prostate cancer cells from apoptosis by inducing BAD phosphorylation via redundant signaling pathways. J. Biol. Chem. 2006, 281, 27367-27377. [CrossRef]

232. Kinkade, C.W.; Castillo-Martin, M.; Puzio-Kuter, A.; Yan, J.; Foster, T.H.; Gao, H.; Sun, Y.; Ouyang, X.; Gerald, W.L.; Cordon-Cardo, C.; et al. Targeting AKT /mTOR and ERK MAPK signaling inhibits hormone-refractory prostate cancer in a preclinical mouse model. J. Clin. Invest. 2008, 118, 3051-3064. [CrossRef] [PubMed]

233. Weston, C.R.; Balmanno, K.; Chalmers, C.; Hadfield, K.; Molton, S.A.; Ley, R.; Wagner, E.F.; Cook, S.J. Activation of ERK1/2 by deltaRaf-1:ER* represses Bim expression independently of the JNK or PI3K pathways. Oncogene 2003, 22, 1281-1293. [CrossRef] 
234. Nickols, N.G.; Nazarian, R.; Zhao, S.G.; Tan, V.; Uzunangelov, V.; Xia, Z.; Baertsch, R.; Neeman, E.; Gao, A.C.; Thomas, G.V.; et al. MEK-ERK signaling is a therapeutic target in metastatic castration resistant prostate cancer. Prostate Cancer Prostatic Dis. 2019, 22, 531-538. [CrossRef] [PubMed]

235. Gioeli, D.; Mandell, J.W.; Petroni, G.R.; Frierson, H.F., Jr.; Weber, M.J. Activation of mitogen-activated protein kinase associated with prostate cancer progression. Cancer Res. 1999, 59, 279-284. [PubMed]

236. Arai, S.; Varkaris, A.; Nouri, M.; Chen, S.; Xie, L.; Balk, S.P. MARCH5 mediates NOXA-dependent MCL1 degradation driven by kinase inhibitors and integrated stress response activation. eLife 2020, 9, e54954. [CrossRef]

237. Nakahara, T.; Kita, A.; Yamanaka, K.; Mori, M.; Amino, N.; Takeuchi, M.; Tominaga, F.; Hatakeyama, S.; Kinoyama, I.; Matsuhisa, A.; et al. YM155, a novel small-molecule survivin suppressant, induces regression of established human hormone-refractory prostate tumor xenografts. Cancer Res. 2007, 67, 8014-8021. [CrossRef]

238. Krajewska, M.; Krajewski, S.; Banares, S.; Huang, X.; Turner, B.; Bubendorf, L.; Kallioniemi, O.-P.; Shabaik, A.; Vitiello, A.; Peehl, D.; et al. Elevated expression of inhibitor of apoptosis proteins in prostate cancer. Clin. Cancer Res. 2003, 9, $4914-4925$. 